\title{
Identification of the Mineral Phases \\ Responsible for Cementation of Lurgi Spent Oil Shale
}

\section{Topical Report}

\author{
M. Brown \\ G. Huntington \\ T. Brown
}

February 1991

Work Performed Under Cooperative Agreement No.: DE-FC21-86MC11076

For

U.S. Department of Energy

Office of Fossil Energy

Morgantown Energy Technology Center

Morgantown, West Virginia

By

Western Research Institute

Laramie, Wyoming

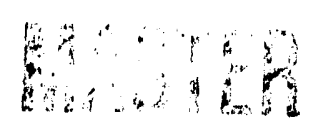




\section{DISCLAIMER}

This report was prepared as an account of work sponsored by an agency of the United States Government. Neither the United States Government nor any agency thereof, nor any of their employees makes any warranty, express or implied, or assumes any legal liability or responsibility for the accuracy, completeness or usefulness of any information, apparatus, product, or process disclosed, or represents that its use would not infringe privately owned rights. Reference herein to any specific commercial product, process, or service by trade name, trademark, manufacturer, or otherwise, does not necessarily constitute or imply its endorsement, recommendation, or favoring by the United States Government or any agency' thereof. The views and opinions of authors expressed herein do not necessarily state or reflect those of the United States Government or any agency thereof.

This report has been reproduced directly from the best available copy.

Available to DOE and DOE contractors from the Office of Scientific anú Technical Information, P.O. Box 62, Oak Ridge, TN 37831; prices available from (615)576-8401, FTS 626-8401.

Available to the public from the National Technical Information Service. U.S. Department of Commerce, 5285 Port Royal Rd., Springfield, VA 22161. 


\section{Identification of the Mineral Phases Responsible for Cementation of Lurgi Spent Oil Shale}

Topical Report

M. Brown

G. Huntington

T. Brown

Work Performed Under Cooperative Agreement No.: DE-FC21-86MC11076

For

U.S. Department of Energy

Office of Fossil Energy

Morgantown Energy Technology Center

P.O. Box 880

Morgantown, West Virginia 26507-0880

By

Western Research Institute

P.O. Box 3395

University Station

Laramie, Wyoming 82071

rebruary 1991 
IIST OF TABLE AND FIGURES.........................

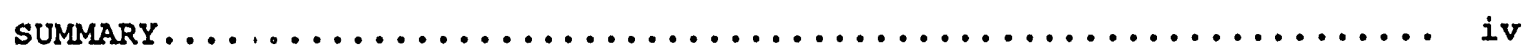

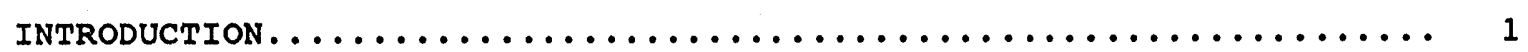

MATERIALS AND METHODS..............................

sample source.................................... 1

Column Preparation.................................

X-ray Diffraction Analyses............................ 2

Scanning Electron Microscrpy/Energy Dispersive X-ray Analyses... 3

Differential Thermal Analyses........................ 3

Tharmogravimetric Analyses ......................... 3

RESULTS AND DISCISSION ............................. 4

$x$-ray Diffraction Analyses.............................4

Scanning Electson Microscopy-Energy Dispersive X-ray Analyses... 5

Thermogravimetric Analyses........................... 12

Differential Thermal Analyses.......................... 20

CONCLUSIONS....................................... 23

RECOMMENDATIONS .................................. 24

ACKNOWLEDGMENTS .................................. 25

DISCLAIMER ...................................... 25

REFERENCES ........................................ 26

APPENDIX A. Y.ray Diffractograms of the Unhydrated and Hydrated Lurgi spent oil shales.................. 28

APPENDIX B. Energy Dispersive x-ray Analyses................ 55 


\section{LIST OF TABLES AND FIGURES}

Table

Page

1. Mineral phases in the Lurgi spent shale Io'entified by $X-r a y$ Diffraction Analysis............................ 4

2. Major Minerals in Spent Unhydrated Shale (Marcus et al. 1985).. 5 Figure

Page

1. X-ray Diffractogram Comparing Unhydrated and Hydrated Spent Lurgi oil shale from 18 to $21 \circ 20 \ldots \ldots \ldots \ldots \ldots \ldots \ldots \ldots . \ldots \ldots . . \ldots$

2. SEM Photographs of Hydrated Lurgi oil Shales (a) the 14-day at x254 Magnification and (b) the 56-day at x352 Magnification.... 7

3. SEM Photographs of Hydrated Lurgi oil shales (a) the 14-day at x1390 Magnification and (b) the 56-day at x1030 Magnification.

4. SEM Pinotographs of the Rod-like Crystals in the 17-day

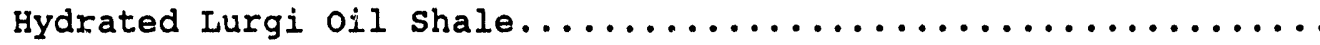

5. Energy Dispersive X-ray Analysis of Cementing Material in Hydrated Lurgi oil shale......................... 10

6. Energy Dispersive $\mathrm{x}$-ray Analysis of Calcite.............. 11

7. Weight Loss Between 100 and $530^{\circ} \mathrm{C}$ for the 308 Water Columns.... 13

8. Thermal Curves of Unhydrated, Lurgi-Processed Oil shale (a) Differential Thermal Analyses and (b) Thermogravimetric Analyses 14

9. Thermal Curves of Lurgi-Processed Oil shale Cured with 308 Water for 1 Day (a) Differential Thermal Analyses and (b) Thermogravimetric Analyses......................... 15

10. Thermal Curves of Lurgi-Processed oil shale cured with 308 Water for 14 Days (a) Differential Thermal Analyses and (b) Thermogravimetric Analyses....................... 16

11. Thermal Curves for Lurgi-Processed oil shále Cured with $30 \%$ Water for 56 Days (a) Differential Thermal Analyses and (b) Thermogravimetric Analyses........................

12. Thermal Curves of Lurgi-Processed oil shale Cured with 208 Water for 1 Day (a) Differential Thermal Analyses and (b) Thermogravimetric Analyses........................ 18

13. Thermal Curves of Lurgi-Processed oil shale Cured with $20 \%$ Water for 17 days (a) Differential Thermal Analyses and (b) Thermogravimetric Analyses......................... 19

14. Total Weight Loss upon Heating for the 308 Water Columns...... 21 


\section{SUMALRY}

Very large volumes of solid waste are generated during oil shale retorting due to the low percentages of organics $(10-308)$ in the oil. shale materials. Therefore, a large amount of material must be processed for a given unit of oil product produced. The reclamation and use of these wastes are desirable from an environmental and economical point of view. Two of the primary considerations in the disposal of these wastes are their structural integrity and the leaching of toxics into groundwater. These wastes are termed spent shale and commonly have a pozzolanic character.

The spent shale used in this study was generated from oil shale mined from the Green River Formation in the Piceance Basin of western Colorado. The oil shale was processed using the Lurgi-Ruhrgas method (Schmalfeld 1975). The spent shale was packed in the Harvard miniature apparatus (Soiltest 1964) using three different water contents. subsequently, the columns were allowed to cure for periods ranging from one day to eight weeks.

Four types of analyses were performed on the cured columns. $\mathrm{x}-\mathrm{ray}$ diffraction (XRD), scanning electron microscopy with an energy dispersive $x-r a y$ analyzer (SEM/EDXA), differential thermal analysis (DTA), and thermogravimetric analysis (TGA).

An attempt was made to determine the mineral phase(s) responsible for cementing and the increase in compressive strength. Marcus et al. (1985) concluded that the dissolution of anhydrite, the hydration of periclase, and the increase in calcite were the major mineral-phase changes responsible for the increase in strength of the spent shale. In the present study, we did not detect an increase in the amount of calcite with increasing cure time. Dolomite also remained relatively unchanged over the 56-day period. There was no XRD evidence for the presence of anhydrite; however, minor amounts of gypsim were detected in all but the 56-day sample. Quartz and feldspar decreased with increasing cure time.

These data contradict the findings of Marcus et al. (1985), which showed that the quartz phase is stable. By the 17th day of curing, periclase was completely hydrated and not detected by XRD analysis. We detected an unidentified mineral phase that increased with increasing compressive strength and may be a major constituent of the cementitious material. The presence of a ferrite spinel phase in hydrated spent oil shale is reported by Marcus et al. (1985) and Bentur and crinberg (1982). The identification of the ferrite spinel phase was not conclusive from the XRD analysis done in our study. However, SEM/EDXA analysis identified $\mathrm{Fe}$ in all of the cured samples. In addition, Mg, Al, $S i, K$, and $C a$ were detected in all of the samples. SEM photomicrographs reveal an increase of cementation over the 56 days of curing. The photomicrographs also show an increase in the growth of clusters of rod-like crystals. The chemistry of these rod-like crystals is dominated by $\mathrm{Ca}, \mathrm{si}$, and $\mathrm{s}$ with minor amounts of $\mathrm{Mg}, \mathrm{Al}$, and $\mathrm{K}$. However, the mineral associated with the rod-like material has not been identified. Identification of the cementing material bridging between 
the spent shale particles was attempted using EDXA. The EDXA spectra of this material was analogous to the spectra for calcite (Welton 1984). However, because the amount of the bridging material in the samples was low, the spectra may have been influenced by the mineralogy of the spent shale particles.

DTA and TGA analyses were performed on the cured samples in two different atmospheres: nitrogen and carbon dioxide. There was little difference noted between the two atmospheres for analysis temperatures below $530^{\circ} \mathrm{C}\left(986^{\circ} \mathrm{F}\right)$. However, there were differences above $530^{\circ} \mathrm{C}$ $\left(986^{\circ} \mathrm{F}\right)$. Decreasing carbonate content with increasing curing time was indicated by comparing thermal curves in carbon dioxide atmospheres with those in nitrogen atmospheres. Thermal analyses were also used to correlate weight loss with unconfined compressive strength. Weight loss events between $100-530^{\circ} \mathrm{C}\left(212-986^{\circ} \mathrm{F}\right)$ are caused by reactions involving the loss of bound water; however, this water loss is not well understood. The results of the thermal analyses suggest that a hydrated, clay-like mineral may be responsible for the increase in compressive strength. Carbonate dissolution may help identify components that are responsible for the formation of cementitious material. 


\section{INTRODUCTION}

Large volumes of solid waste are generated during the extraction of fuels from oil shals. When disposing these wastes, there are two primary concerns. Structural integrity is an important consideration for the design of stable waste piles, and leaching of toxic compounda into surface-water groundwater is the other major consideration. This report presents the results of a study using x-ray diffraction, SEM/EDXA, thermogravimetric analyses, and differential thermal analyses to define the chemical nature of the cementing agents responsible for the structural strength of processed oil shale.

Turner and Rothwell (1991) report that oil shale solid wastes generated using the Lurgi-Ruhrgas method increased in strength, durability, and resilient modulus with increased water content and increased curing time. The optimal water content for material strength is about 308. A 308 water content produced greater structural strength than a 208 water content (Rothwell 1989). Further experimentation is needed before a more exact optimal water content can be determined. Turner and Rothwell (1991) also report that material strength increased with curing time to 28 days.

There are several possible reasons for the increased strength with increased water content. Turner and Rothwell (1991) suggest that cementing is being done by hydrated minerals. Marcus et al. (1985) noted that the amounts of $\mathrm{CaSO}_{4}$ and Mgo decreased upon hydration in a similar spent oil shale. It is certainly possible that these minerals are involved with the formation of hydrates during the curing process. The minerals that form during the process probably represent numerous types and forms. Bridging materials in a similar spent shale included calcium and magnesium carbonates, hydroxycarbonates, and complex aluminum and silicon compounds of the alkaline earth elements (Marcus et al. 1985).

The purpose of this study is to investigate the mineralogical character of the cements that are responsible for the increased strength of the spent oil shale. Several techniques to identify the nature of the cementing agents have been used in this study. $\mathrm{x}$-ray diffraction was used to identify mineral dissolution and formation; scanning electron microscopy (SEM) was used to observe the cementing agents; energy dispersive $\mathrm{X}$-ray analysis (EDXA) was used to provide information on the elemental composition of both the bulk material and the cementing agents; and differential thermal analyses and thermogravimetric analyses were used to document the presence of suspected minerals that may be involved in formation of the cementing material.

\section{MATERIALS AND METHODS}

\section{Sample Source}

The oil shale solid waste studied was a byproduct of the LurgiRuhrgas processing method used by Rio Blanco oil shale company Inc. The solid byproduct remaining after the extraction of kerogen from oil shale 
consists of two components. One is collected in solid surge bins and the other in flue filters. In general, the flue dust from the filters is much finer-grained than the surge-bin solids.

The two waste products were stored separately after processing. The surge-bin waste was placed in large storage bags each weighing approximately $1000 \mathrm{lb}$. The flue dust was placed in 55-gal steel drums. Rio Blanco oil shale Company Inc. estimated that approximately 108 by weight of the processed shale consists of flue dust.

Twenty bags of surge bin solids and one 55-gal drum of flue dust were obtained from the Rio Blanco oil shale Company Inc. for this study. The samples were chosen at random and comprise only a small percentage of the total volume of stored spent shale at the site (Rothwell 1989).

\section{Column Preparation}

Columns consisting of processed oil shale and water were prepared to test engineering properties and to evaluate the mineralogical characteristics of the material. Compacted columns were prepared by the University of Wyoming's Department of Civil Engineering (UW). The columns were made using either a 20 or a 308 water content. The columns were allowed to cure for these specified periods: 1 day, 208 water; 1 day, 308 water; 17 days, 208 water; 14 days, 308 water; and 56 days, 308 water. The columns were wrapped in cellophane to minimize the loss of water by evaporation during the curing period.

The water in the columns was removed by flushing with ethanol to stop the curing process at the specified time. Ethanol was used because it is considered a non-reactive substance and would not influence the mineralogy of the materials. This method eliminates or reduces curing and prevents changes in the samples that may occur prior to analysis. Four to five pore volumes of ethanol were passed through the columns before UW submitted thom to WRI for study.

\section{X-ray Diffraction Analyses}

The unhydrated and hydrated spent oil shale samples were initially crushed with a hammer in ziplock bags. The crushed sampl, were then ground with a mortar and pestle to $<1 \mathrm{~mm}$ and predominantly $<0.05 \mathrm{~mm}$. They were dried overnight in an oven at $100^{\circ} \mathrm{C}\left(212^{\circ} \mathrm{F}\right)$, cooled in a desiccator, and sifted through a 45- $\mu \mathrm{m}$ sieve. Approximately $2 \mathrm{~g}$ of each sample was mounted on glass slides using a mixture of acetone and Ducco cement for random sample orientation. The acetone/Ducco cement mixture was shown not to alter the mineralogy of the material in a preliminary comparison with an ethanol slurry. The acetone/Ducco cement mixture was prepared at approximately a 5-to-1 ratio. The samples were dried for 1 min under a heat lamp and then air dried for $10 \mathrm{~min}$.

X-ray diffraction analyses were done using an automated, computerdriven scintag PAD $V$ diffractometer system. The diffractoneter is equipped with an intrinsic germanium, solid-state detection system and computer-assisted, user-interactive software supplied by the manufacturur. The system was operated at $45 \mathrm{kV}$ and $40 \mathrm{~mA}$ using $\mathrm{Ni}-$ 
filtered cuka radiation. spectra were acquired from 2 to $62^{\circ} 2 \theta$ at 2。/min. Each sample was then remounted and rerun to test reproducibility.

The diffractograms were compared to Joint Committee on Powder Diffraction standards (JCPDS) files for phase identification. $x-r a y$ diffractograms of the unhydrated and hydrated Lurgi samples are illustrated in Appendix A.

Scanning Electron Microscopy/Energy Dispersive X-ray Analyses

The samples cured for 14 and 56 days were the strongest and least friable of the columns. Therefore, we used these samples for further study. We attempted to obtain a sample of the 17-day core but were unsuccessful. Two of the sample columns were cut and mounted on aluminum stubs using colloidal graphite. The use of solid rather than crushed samples prevents the cementing materials from being masked by topography. The unhydrated sample was also mounted for analysis. The samples were then coated with gold using an Edwards sputter Coater S150B.

SEM/EDXA was performed using an Amray model 1820 computer-enhanced, digital-imaging scanning electron microscope (100-s count, $15.00 \mathrm{kV}$, 35.00 take-off ang $\cdots$. The SEM is equipped with a Tracor Northern model 5500 series II fully computer-operated energy dispersive $x-r a y$ analyzer (EDXA), which was used for semiquantitative elemental determinations.

\section{Differential Thermal Analyses}

Differential thermal analyses were performed with a Perkin-Elmer DTA 1700 differential thermal analyzer (DTA). The DTA was controlled by a Perkin-Elmer system $7 / 4$ thermal analysis controller and Perkin-Elmer PC series thermal analysis system software, which was run on a PC Limited 286 personal computer. Calibrations were performed as described in the operator's manual provided by Perkin-Elmer (1989a).

The reference cup of the DTA was filled with $50 \mathrm{mg}$ of aluminum oxide $\left(\mathrm{Al}_{2} \mathrm{O}_{3}\right)$. The sample cup contained about $40 \mathrm{mg}$ of powdered sample, with about $5 \mathrm{mg}$ of aluminum oxide on both the top and bottom of the sample. The sample cups were made of aluminum oxide.

Two runs were performed on each of the six samples. The furnace chamber was pu:ged wj.th $50 \mathrm{~cm}^{3} / \mathrm{min}$ of nitrogen for one run, and 50 $\mathrm{cm}^{3} / \mathrm{min}$ of carbon dioxide was used for the other run. Each sample was heated from 80 to $1020^{\circ} \mathrm{C}\left(176\right.$ to $1868^{\circ} \mathrm{F}$ ) at a constant rate of $20^{\circ} \mathrm{C} / \mathrm{min}$ $\left(68^{\circ} \mathrm{F} / \mathrm{min}\right)$. The temperatures of the reference and sample cups were measured by thermocouples located directly beneath the cups.

Thermogravimetric Analyses

Thermogravimetric analyses were performed with a Perkin-Elmer TGA 7 thermogravimetric analyzer (TGA). The TGA was controlled by a PerkinElmer TAC 7/PC instrument controller, which was operated by Perkin-Elmer 
PC series thermal analysis system software run on a PC Limited 286 personal computer. Calibrations were performed as specified in the manufacturer's operator's manual (Perkin-Elmer 1989b)

TGA samples were prepared in the same manner as the samples used for DTA. Platinum sample cups were loaded with $55 \mathrm{mg}$ of powdered sample. Samples were heated from 100 to $1020^{\circ} \mathrm{C}\left(21.2\right.$ to $\left.1868^{\circ} \mathrm{F}\right)$ at a constant rate of $20^{\circ} \mathrm{C} / \mathrm{min}\left(68^{\circ} \mathrm{F}\right)$. Two runs were performed on each of the six samples. The furnace chamber was purged with $50 \mathrm{~cm}^{3} / \mathrm{min}^{\circ}$ of nitrogen or carbon dioxide for each sample.

\section{RESULTS AND DISCUSSION}

\section{X-ray Diffraction Analyses}

Comparisons of five hydrated samples and one unhydrated sample were made using XRD. The mineral phases that were positively identified in the Lurgi samples by XRD analysis are shown in Table 1.

Table 1. Mineral Phases in the Lurgi spent shale Identified by $x-r a y$ Diffraction Analysis

\begin{tabular}{llllll}
\hline & \multicolumn{1}{c}{1 day, } & \multicolumn{1}{c}{1 day, } & 14 day, & 17 day, & 56 day, \\
Unhydrated & 208 water & 308 water & 308 water & 208 water & 308 water \\
\hline Quartz & Quartz & Quartz & Quartz & Quartz & Quartz \\
Calcite & Calcite & Calcite & Calcite & Calcite & Calcite \\
Feldspar & Feldspar & Feldspar & Feldspar & Feldspar & Feldspar \\
Dolomite & Dolomite & Dolomite & Dolomite & Dolomite & Dolomite \\
Gypsum & Gypsum & Gypsum & Gypsum & Gypsum & \\
Periclase & Periclase & Periclase & Periclase & & \\
& & & & &
\end{tabular}

Calcite $\left(\mathrm{CaCO}_{3}\right)$ and dolomite $\left(\mathrm{CaMg}\left(\mathrm{CO}_{3}\right)_{2}\right)$ peaks were the only minerais to remain relatively unchanged over the 56-day cure period. The quartz $\left(\mathrm{SiO}_{2}\right)$, feldspar $\left(\mathrm{NaAlsi}_{3} \mathrm{O}_{8}-\mathrm{KAlSi}{ }_{3} \mathrm{O}_{8}\right)$, and periclase (MgO) peaks all decrease with cure time. These results conflict with the data reported by Marcus et al. (1985), which lists quartz as an unchanged mineral phase. A deconvolution program was run using software provided by scintag to determine the presence of gypsum $\left(\mathrm{CasO}_{4}\right)$. Minor amounts of gypsum were detected in all but the 56-day hydrated Lurgi sample.

We did not detect peaks that correspond with the minerals illite, anhydrite, hematite, andlcime, pyrite, corundum, or magnesite. All of these phases were reported by Marcus et al. (1985) as occurring in either hydrated or unhydrated spent oil shales. The samples were magnetic, which is caused by an unidentified iron oxide phase. Also, there were a few unidentified peaks within all of the samples that will need to be studied further.

We expect many minerals to be present in unhydrated Lurgi spent oil shale (Table 2). In this study, we were unable to confirm the presence 
of $\mathrm{Al}_{2} \mathrm{O}_{3}, \mathrm{Fe}_{2} \mathrm{O}_{3}$, and $\mathrm{CaO}$. A possible explanation for the lack of such minerals may be the loss or alteration of these minerals during sample transport and preparation.

Table 2. Major Minerals in Unhydrated Spent Shale (Marcus et al. 1983)

$\begin{array}{ll}\text { Quartz } & \mathrm{SiO}_{2} \\ \text { Corundum } & \mathrm{Al}_{2} \mathrm{O}_{3} \\ \text { Hematite } & \mathrm{Fe}_{2} \mathrm{O}_{3} \\ \text { Lime } & \mathrm{CaO} \\ \text { Periclase } & \mathrm{MgO} \\ \text { Anhydrite } & \mathrm{CaSO}_{4}\end{array}$

An unidentified mineral with a peak at $19.7^{\circ} 2 \theta$ was obse: ved in the unhydrated Lurgi sample that is not evident in the hydrated phase (Figure 1). This mineral is a likely source of the material responsible for cementation of spent oil shale. To date, this mineral has not been identified. The cementitious material probably contains mineral phases in concentrations less than the 5-108 needed for XRD identification, or is in an amorphous form. Amorphous phases can not be detected by XRD.

\section{Scanning Electron Microscopy/Energy Dispersive X-ray Analynes}

Elements consistently deterted in the samples were $\mathrm{Mg}, \mathrm{Al}, \mathrm{Si}, \mathrm{K}$, $\mathrm{Ca}$, and $\mathrm{Fe}$. The amount of individual and separate particles decreases as cure time increases (Figure 2). An obvious increase in cementation and bridging between particles is shown in Figure 3 . Spent shale particles, calcite rhombohedrons, and small rod-shaped crystals occurred in the 14-day sample. We also detected many clusters of hexagonal rodlike minerals in the samples (Figure 4). Spectral analysis of these crystals using EDXA shows that their elemental make-up is dominated by $\mathrm{Ca}, \mathrm{Si}$, and $\mathrm{S}$ with $\mathrm{Mg}, \mathrm{Al}$, and $\mathrm{K}$ as minor elements (Appendix $\mathrm{B}$ ). Marcus et al. (1985) report that similar rod-like crystals consisted of Al, Si and $\mathrm{S}$ with minor amounts of $\mathrm{Ca}, \mathrm{K}$ and $\mathrm{Mg}$.

One of the problems that we encountered with EDXA use in this study was difficulty in focusing on an area that was small enough to distinguish a bridge of cement from the other constituents of the spent oil shale. The elementai analysis of a cementing material detected in one sample wes dominated by $\mathrm{Ca}$ (Figure 5 ). This spectra compares well with a typical calcite spectra as noted by Welton (1984) (Figure 6). However, because the $\mathrm{X}$-ray diffraction data does not show an increase in the calcite peaks, it is difficult to conclude that calcite is an active cementing agent. In fact, calcite is probably not a significant cementing agent, but it contributes to cementation by providing constituents that react with $\mathrm{Si}$ and $\mathrm{Al}$ compounds to form cementation material. Essington (1989) examined the cementation process in hydrated Lurgi spent oil shale ard concluded that ettringite is a main cementing constituent. XRD and SEM/EDXA analyses in this study show no evidence of the occurrence of ettringite in the cured spent oil shales. If present, ettringite may occur in low concentrations. 


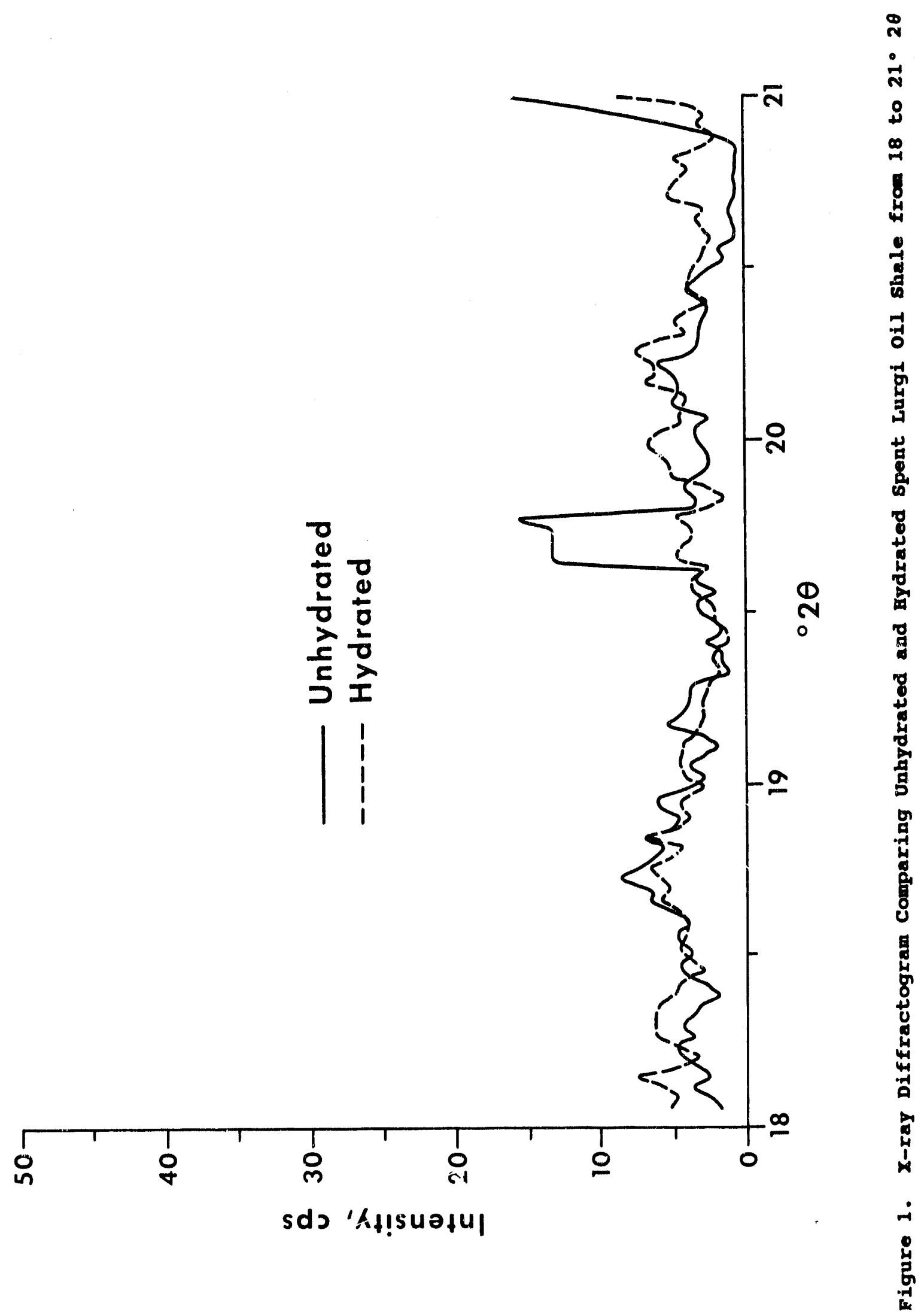




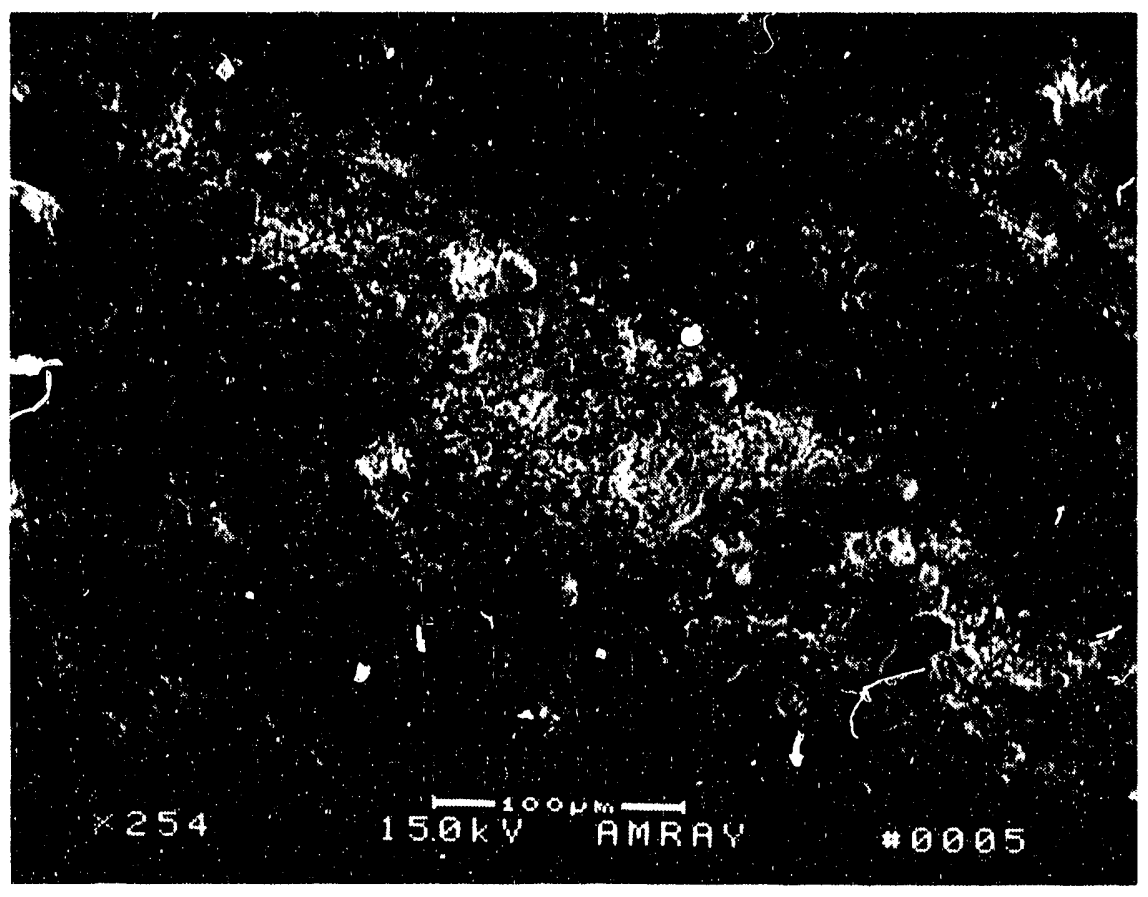

(a)

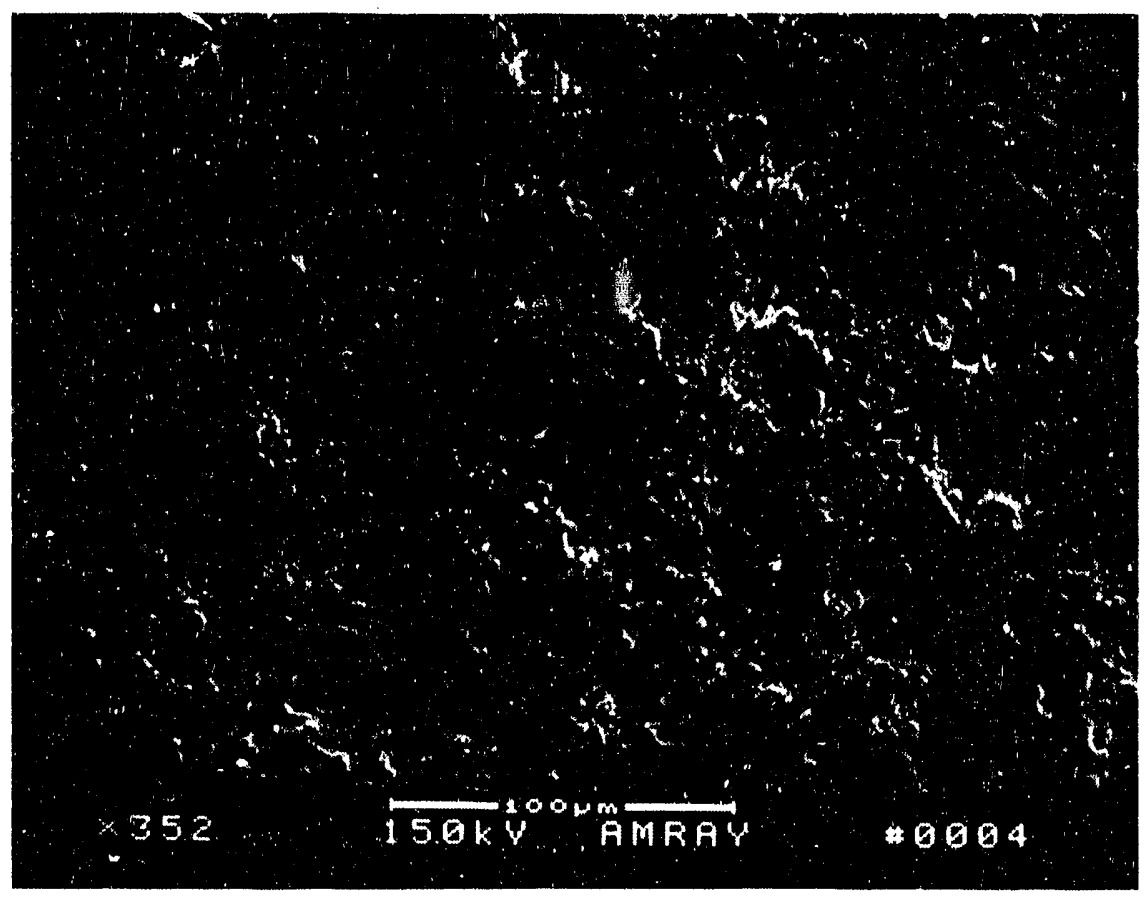

(b)

Figure 2. SEM Photographs of Hydrated Lurgi oil shales (a) the 14-day at $\times 254$ Magnification and (b) the 56-day at $\times 352$ Magnification 


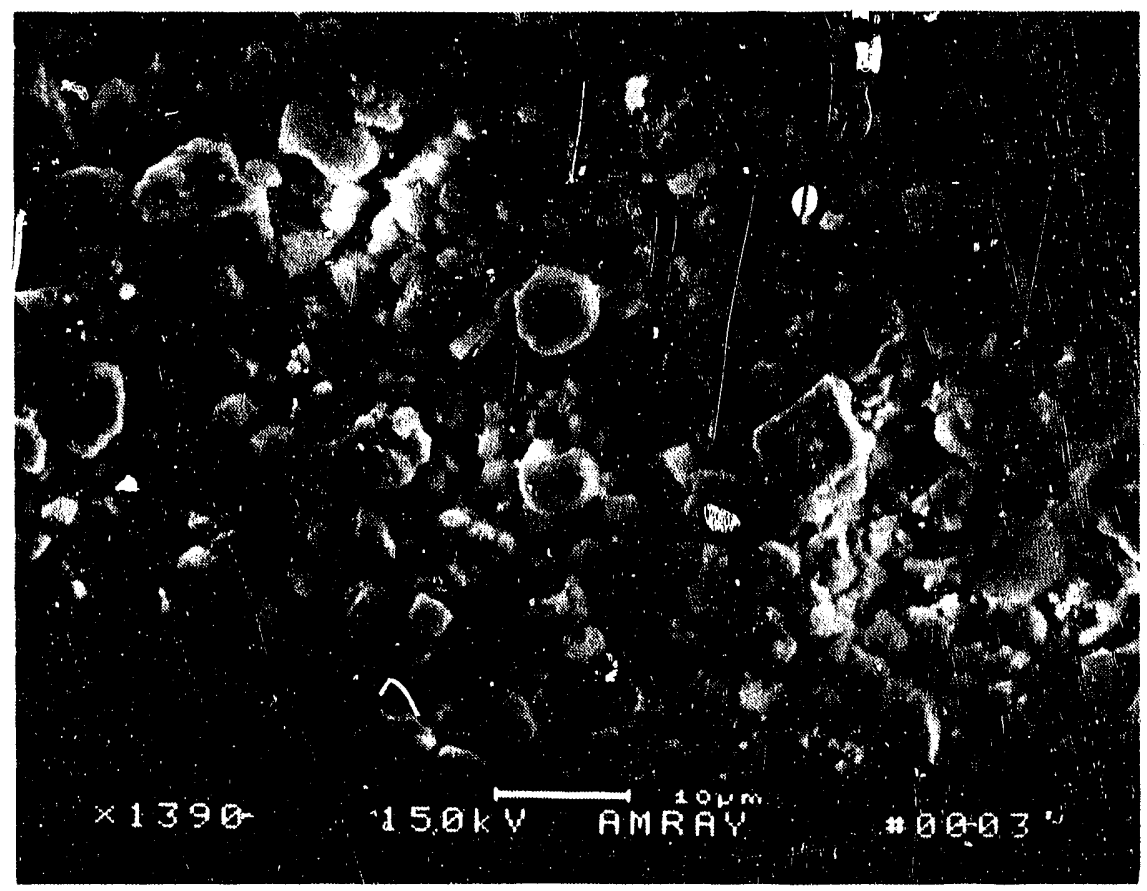

(a)

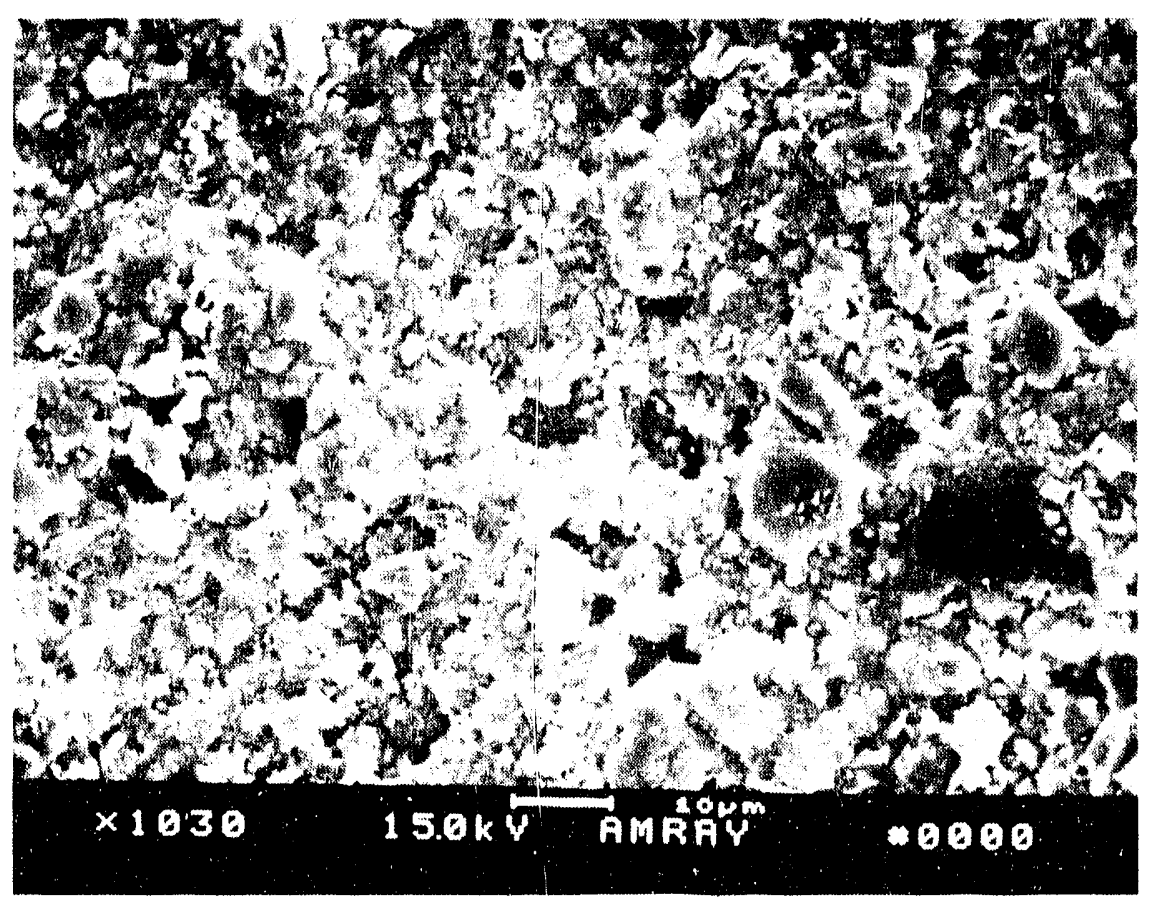

Figure 3. SEM Photographs of Hydrated Lurgi oil Shales (a) the 14-day at $\times 1390$ Magnification and (b) the 56-day at $\times 1030$ Magnification 

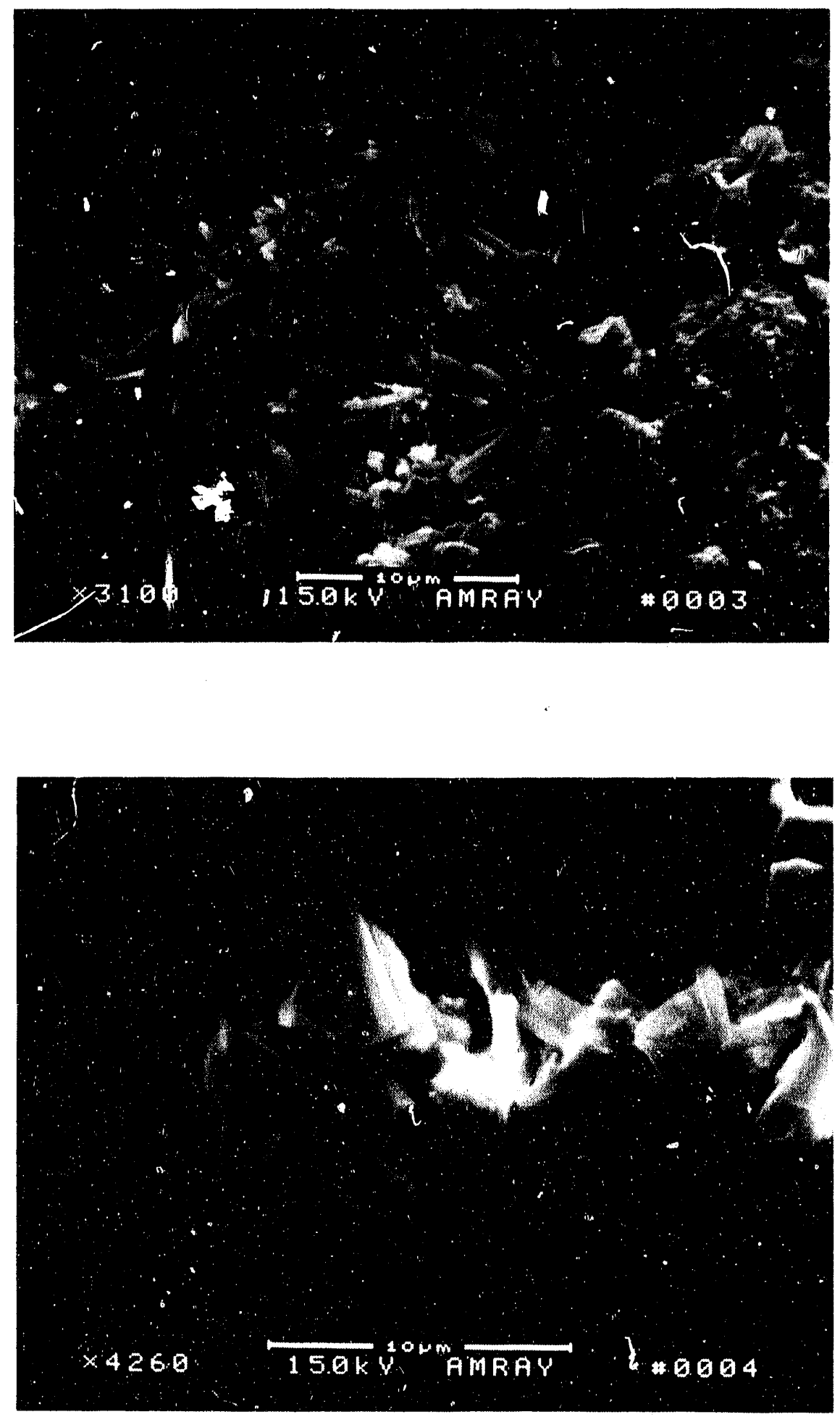

Figure 4. SEM Photographs of the Rod-like Crystals in the 17-day Hydrated Lurgi oil shale 

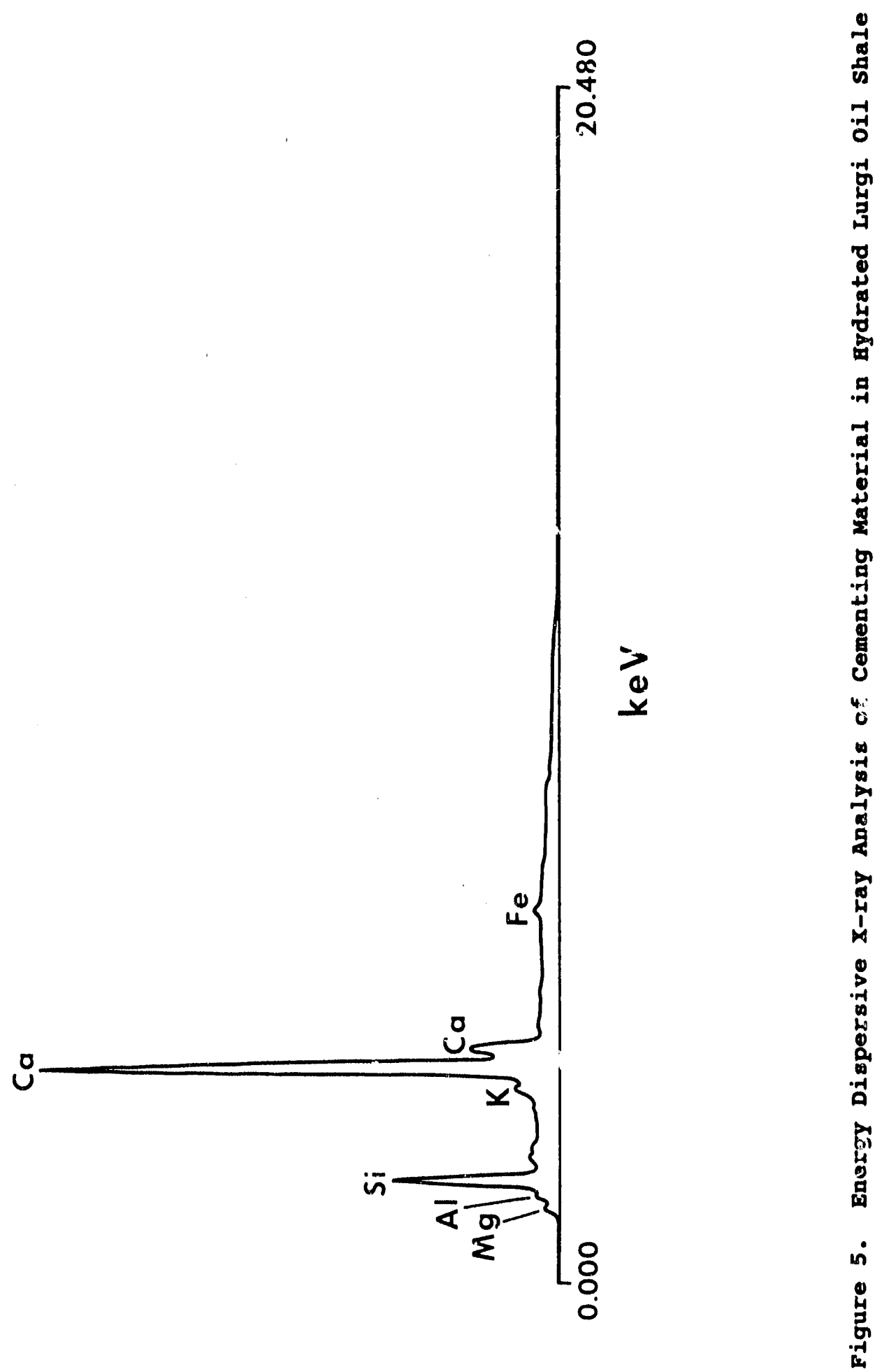


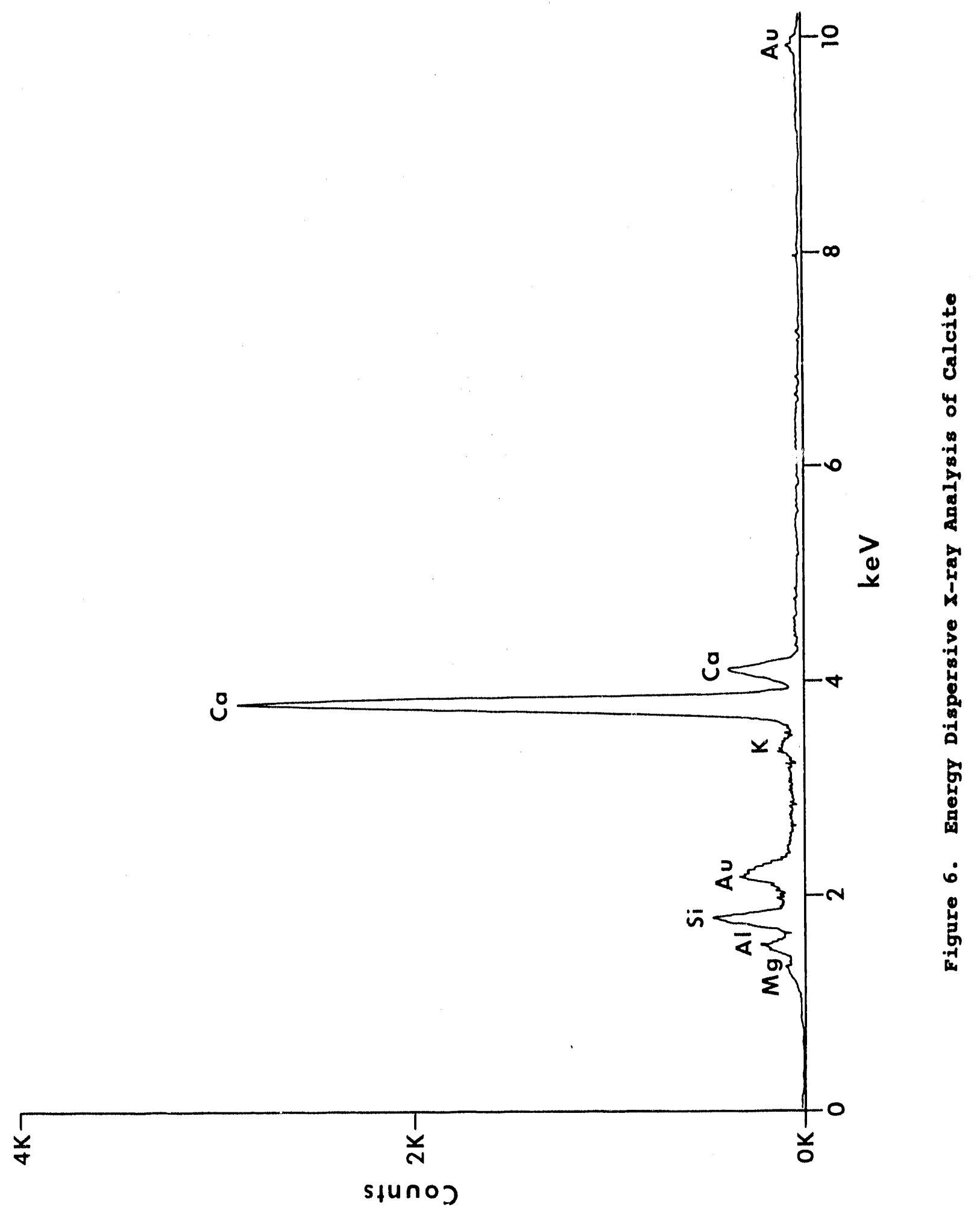




\section{Thermogravimetric Analyses}

Decomposition temperatures of minerals are greatly affected by their chemical and mineralogical makeup (Hendrickson 1975) and by the atmosphere in which decomposition takes place (Warne 1980). For this reason, mineral identification can not be determined strictly from temperatures of decomposition.

The rate of weight 108 s reached a local minima at $\sim 250^{\circ} \mathrm{C}\left(\sim 482^{\circ} \mathrm{F}\right)$ and anothur at $-530^{\circ} \mathrm{C}\left(986^{\circ} \mathrm{F}\right)$. For this reason, we split cur analyses into three temperature ranges: less than $250^{\circ} \mathrm{C}, 250-530^{\circ} \mathrm{C}\left(482^{\circ} \mathrm{F}, 482-\right.$ $\left.986^{\circ} \mathrm{F}\right)$, and greater than $530^{\circ} \mathrm{C}\left(986^{\circ} \mathrm{F}\right)$.

Average weight losses for the thermogravimetric experiments between 100 and $250^{\circ} \mathrm{C}\left(212\right.$ and $\left.482^{\circ} \mathrm{F}\right)$ and between 250 and $530^{\circ} \mathrm{C}$ (482 and $986^{\circ} \mathrm{F}$ ) as a function of curing time are shown in Figure 7 . There was about a twofold increase in weight loss between the unhydrated shale and the one-day samples in the 100 to $250^{\circ} \mathrm{C}\left(212\right.$ to $\left.482^{\circ} \mathrm{F}\right)$ range and in the 250 to $530^{\circ} \mathrm{C}\left(482\right.$ to $\left.986^{\circ} \mathrm{F}\right)$ range. An additional threefold increase in weight loss occurred from the one-day samples to the 14-day samples. The total weight $108 s$ between 100 and $530^{\circ} \mathrm{C}\left(212\right.$ and $\left.986^{\circ} \mathrm{F}\right)$ decreased slightly from the 14-day cured sample to the 56-day cured sample.

The unhydrated spent shale lost 0.38 of its total weight when we heated it from 100 to $250^{\circ} \mathrm{C}\left(212\right.$ to $\left.482^{\circ} \mathrm{F}\right)$, and an additional 0.38 was lost when we heated it from 250 to $530^{\circ} \mathrm{C}\left(482\right.$ to $\left.986^{\circ} \mathrm{F}\right)$. After one day of hydration, the situation changed. Weight $10 \mathrm{ss}$ between 100 and $250^{\circ} \mathrm{C}$ $\left(212\right.$ and $\left.482^{\circ} \mathrm{F}\right)$ increased to 0.58 , whereas the Ioss between 250 and $530^{\circ} \mathrm{C}\left(482\right.$ and $\left.986^{\circ} \mathrm{F}\right)$ increased to 0.68 . The amount of weight loss between 100 and $530^{\circ} \mathrm{C}\left(212\right.$ and $\left.986^{\circ} \mathrm{F}\right)$ changed substantially after 14 days. The weight loss progressed from 0.58 for the unhydrated shale, to 1.18 after one day of curing, to 4.08 after 14 days.

The total weight loss between 100 and $530^{\circ} \mathrm{C}\left(212\right.$ and $\left.986^{\circ} \mathrm{F}\right)$ went from 4.08 after 14 days to 3.98 after 56 days. After 14 days, a 2.08 weight loss occurred between 100 and $250^{\circ} \mathrm{C}\left(212\right.$ and $\left.482^{\circ} \mathrm{F}\right)$, whereas after 56 days a 1.48 weight loss was observed between 100 and $250^{\circ} \mathrm{C}(212$ and $482^{\circ} \mathrm{F}$ ). The situation was reversed at higher temperatures. A 1.98 weight loss occurred between 250 and $530^{\circ} \mathrm{C}\left(482\right.$ and $\left.986^{\circ} \mathrm{F}\right)$ after 14 days of curing. After 56 days, a 2.28 weight loss occurred between 250 and $530^{\circ} \mathrm{C}\left(482\right.$ and $\left.986^{\circ} \mathrm{F}\right)$. The weight $\mathrm{oss}$ shifted from the low-temperature event $\left(100\right.$ to $250^{\circ} \mathrm{C} / 212$ to $\left.482^{\circ} \mathrm{F}\right)$ to the higher temperature event $(250$ to $530^{\circ} \mathrm{C} / 482$ to $986^{\circ} \mathrm{F}$ ) between 14 and 56 days.

The thermogravimetric curves (Figures 8 through 13 ) show an increasing rate of weight loss at $530^{\circ} \mathrm{C}\left(986^{\circ} \mathrm{F}\right)$. Weight loss steadily increased from 600 to $750^{\circ} \mathrm{C}\left(1112\right.$ to $\left.1382^{\circ} \mathrm{F}\right)$ for all samples with little difference caused by changing purge gases. At $750^{\circ} \mathrm{C}\left(1382^{\circ} \mathrm{F}\right)$, the rate of weight loss increased in a nitrogen atmosphere but decrrased in a carbon dioxide atmosphere for all hydrated samples. This effect was most pronounced in the samples cured for 14,17 , and 56 days. Weight loss stopped at $820^{\circ} \mathrm{C}\left(1508^{\circ} \mathrm{F}\right)$ in a nitrogen atmosphere and at $930^{\circ} \mathrm{C}$ $\left(1706^{\circ} \mathrm{F}\right)$ in a carbon dioxide atmosphere. 


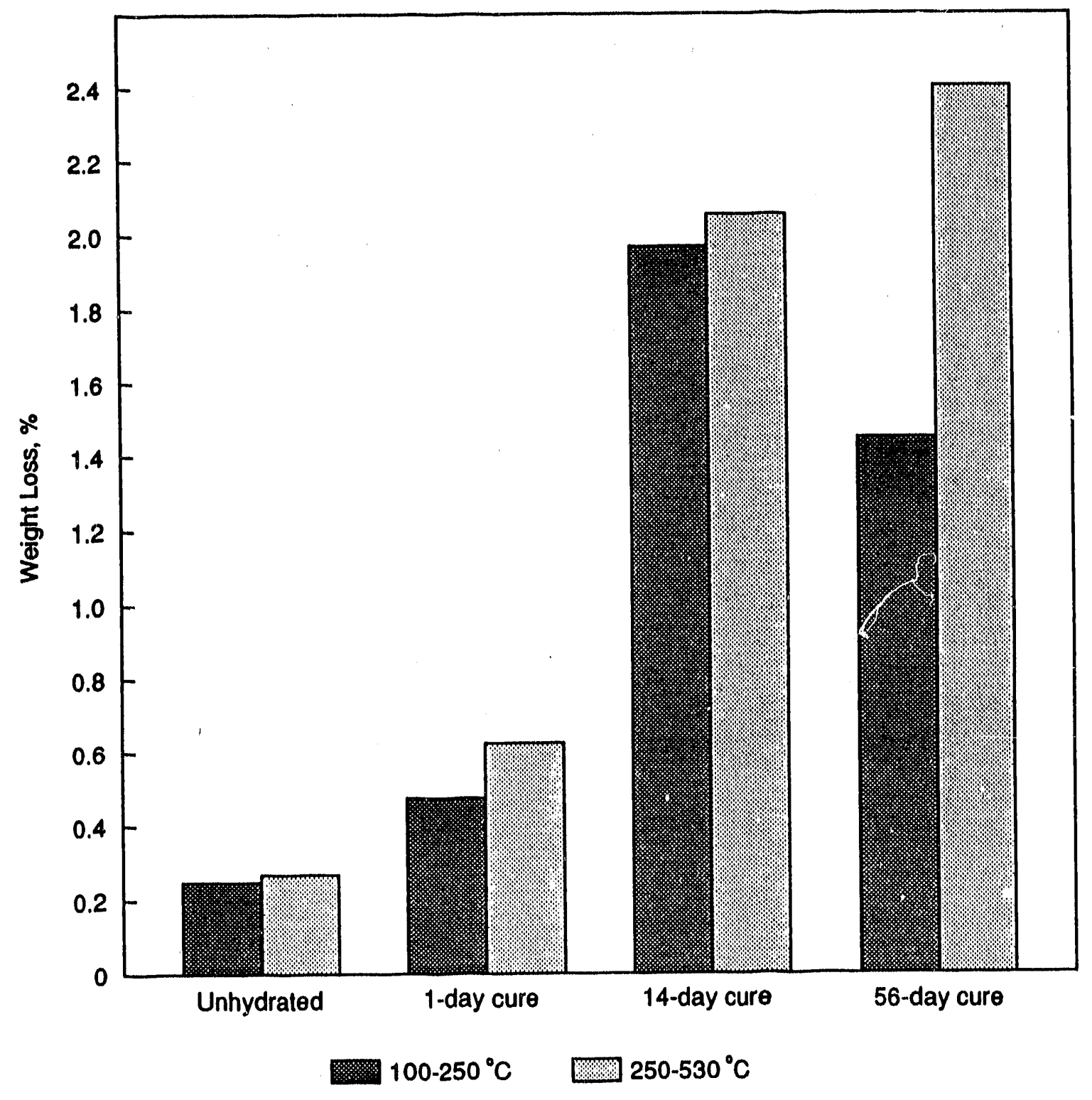

Figure 7. Weight Loss Between 100 and $530^{\circ} \mathrm{C}$ for the $30 z$ Water Columns 


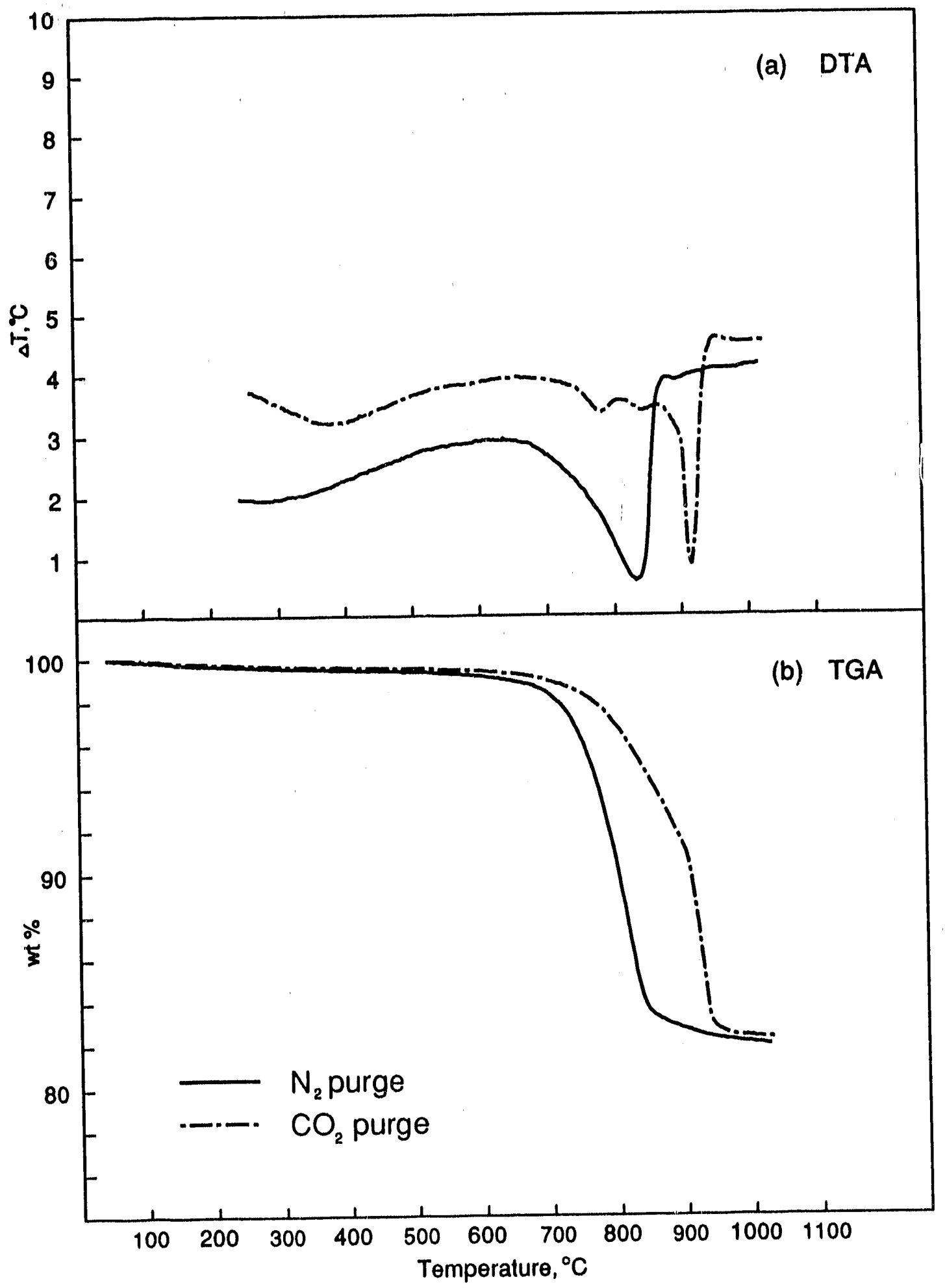

Figure 8. Thermel Curves of Unhydrated, Lurgi-Processed Oil shale, (a) Differential Thermal Analyas and (b) Thermogravimetric Analyses 


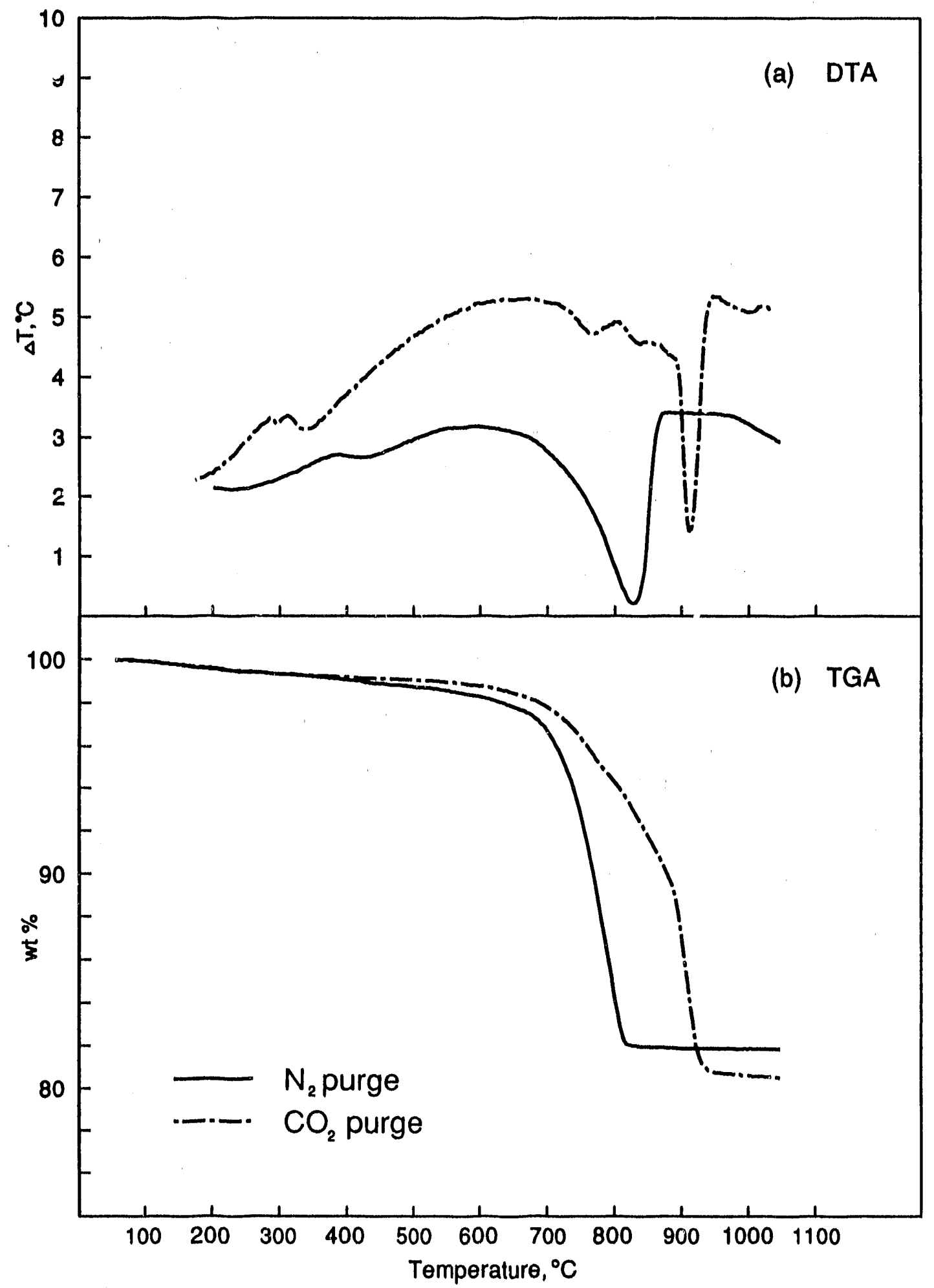

Figure 9. Thermal Curves of Lurgi-Processed oil shale Cured with 308 Water for 1 Day, (a) Differential Thermal Analyses and (b) Thermogravimetric Analyses 


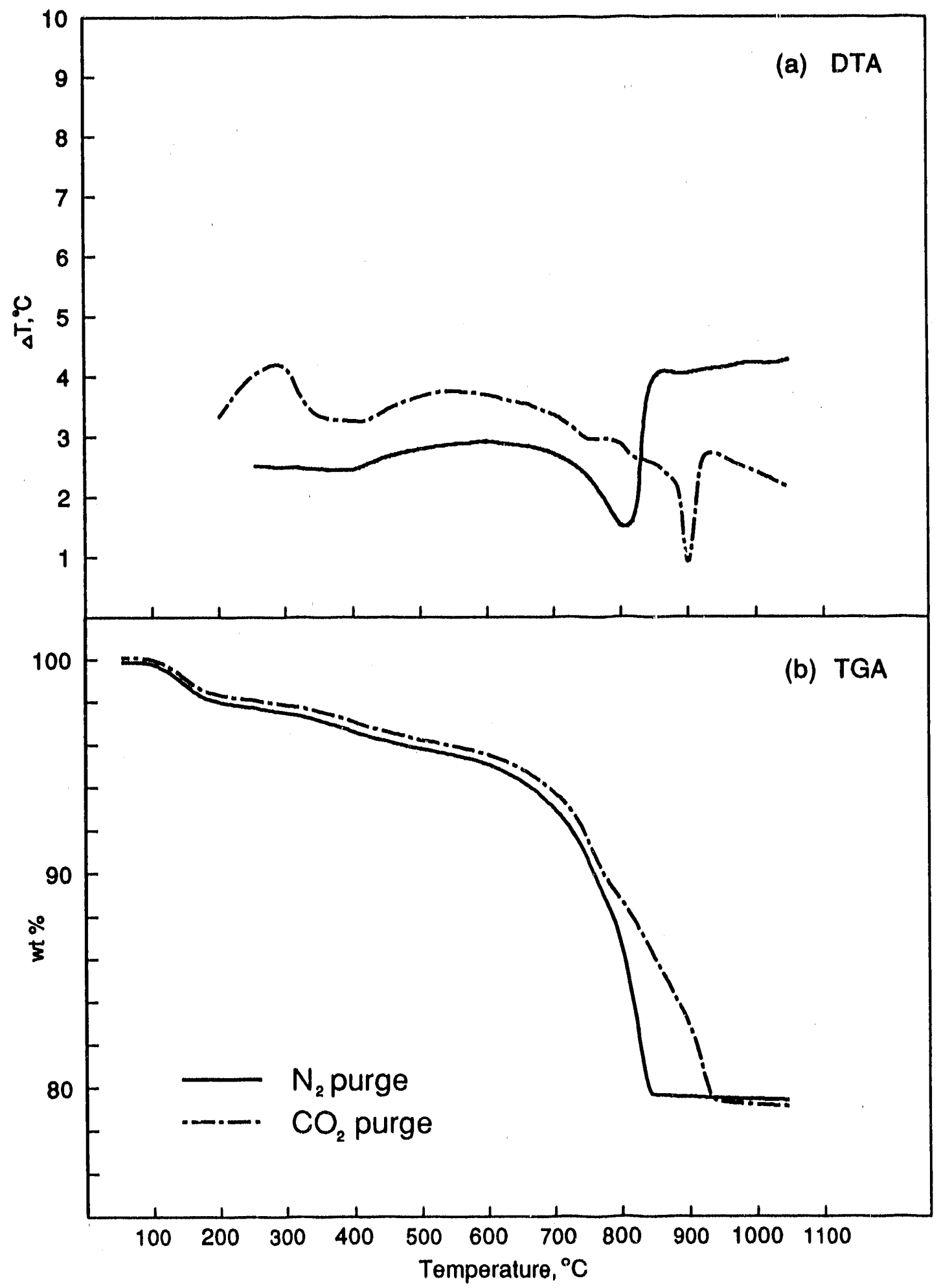

㯊

Figure 10. Thermal Curves of Lurgi-Processed oil shale Cured with 308 Water for 14 Days, (a) Differential Thermal Analyses and (b) Thermogravimetric Analyses 


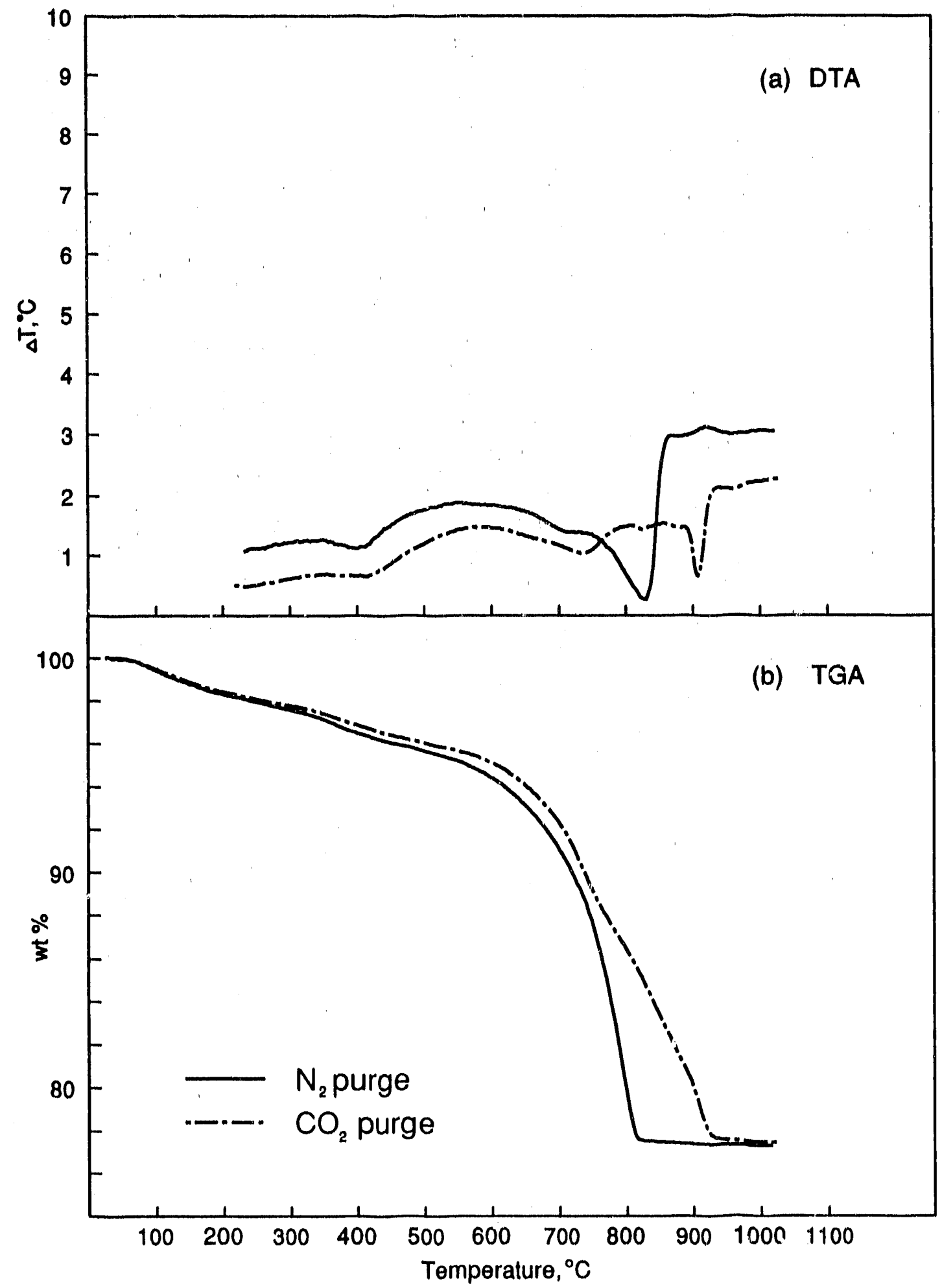

Figure 11. Thermal Curves of Lurgi-Processed oil shale Cured with $30 \%$ Water for 56 Days, (a) Differential Thermal Analyses and (b) Thermogravimetric Analyses 


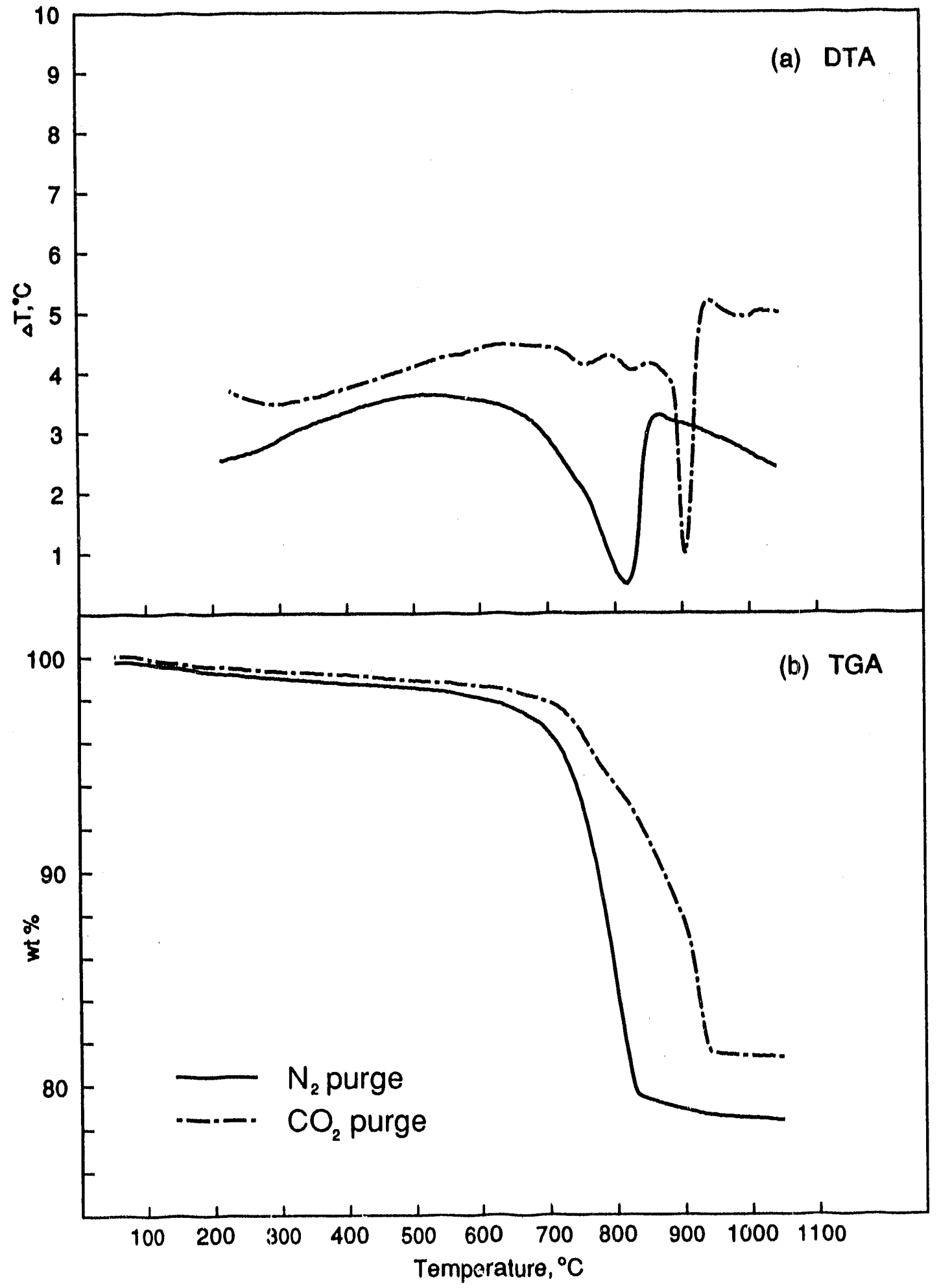

Figure 12. Thermal Curves of Lurgi-Perocessed 0il shale Cured with 208 Water for 1 Day, (a) Differential Analyses and (b) Thermogravimetric Analyses 


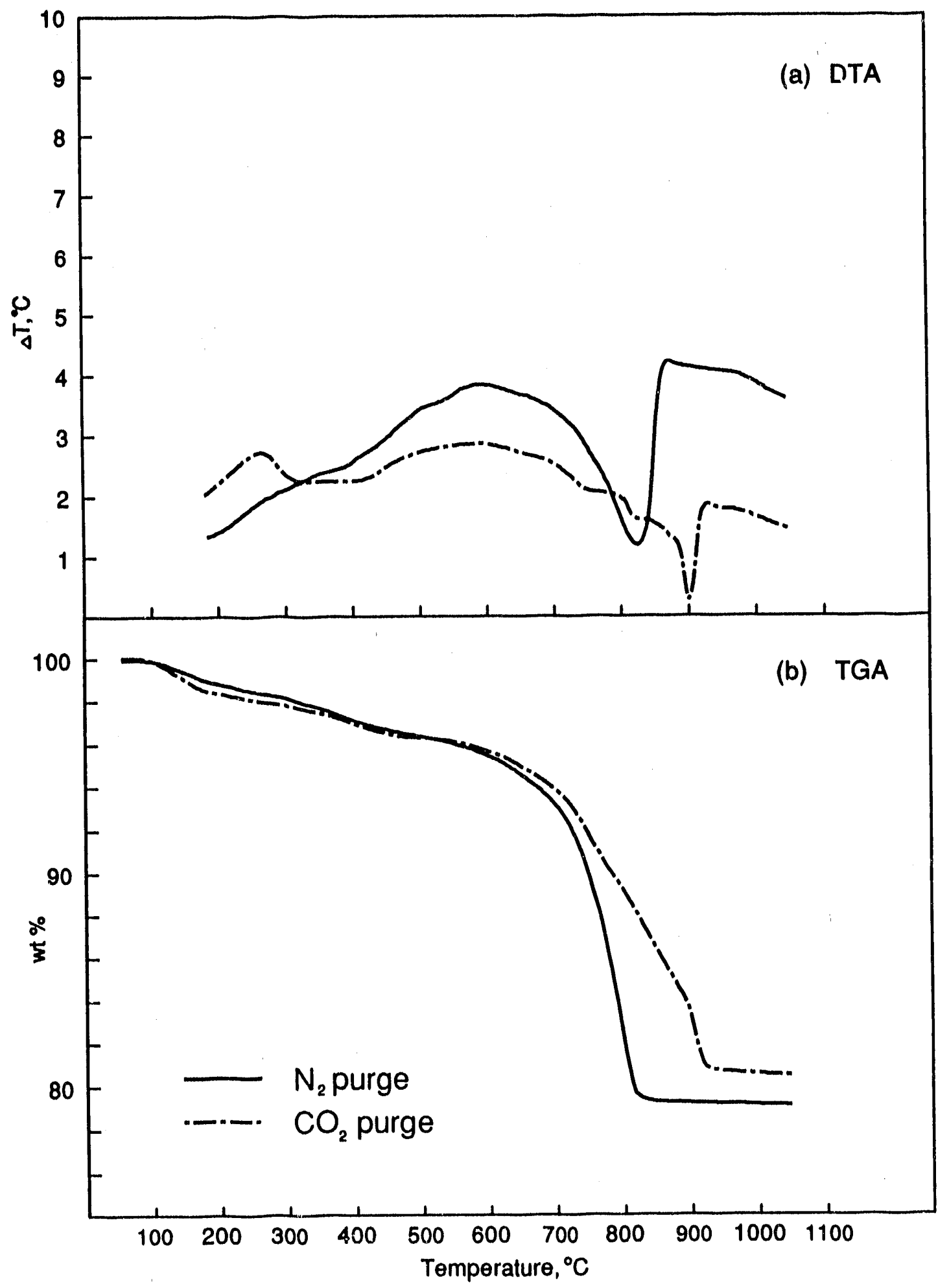

Figure 13. Thermal Curves of Lurgi-Processed 0il shale Crued with 208 Water for 1.7 Days, (a) Differential Thermal Analyses and (b) Thermogravimetric Analyses 
Weight loss below $530^{\circ} \mathrm{C}\left(986^{\circ} \mathrm{F}\right)$ increases with longer curing time. Generally, but not always, loss of waters of hydration occurs at less than $250^{\circ} \mathrm{C}\left(482^{\circ} \mathrm{F}\right.$ ) (Smykatz-Kloss 1974; Dollimore et al. 1981; Marino and Mascolo 1981; Stacey 1981; Horsley and Nowell 1981; Mousty et al. 1981 ; Roessler and odler 1981). Minerals with multiple waters of hydration generaliy lose them in steps when the mineral is pure (Smykatz-Kloss 1974). Dehydroxylation generally occurs at temperatures greater than $200^{\circ} \mathrm{C}\left(392^{\circ} \mathrm{F}\right)$ (Glasser 1983; Marino and Mascolo 1981; Gonzalez-Calbet and Franco 1981; stacey 1981; Todor 1976). Thit suggests that the weight 10 sses we observed below $530^{\circ} \mathrm{C}\left(986^{\circ} \mathrm{F}\right)$ are due to dehydration and dehydroxylation reactions. At least two types of reactions are occurring under $530^{\circ} \mathrm{C}\left(986^{\circ} \mathrm{F}\right)$, since the rate of weight loss reached a local minimum at $250^{\circ} \mathrm{C}\left(482^{\circ} \mathrm{F}\right)$ in all samples that exhibited weight loss over this temperature range (Figures 10, 11 , and 13).

The thermogravimetric curves show a progression from the unhydrated and 1-day through the 56-day cured samples (Figures 8 through 13). The shapes of the curves are similar over $530^{\circ} \mathrm{C}\left(986^{\circ} \mathrm{F}\right)$ for all samples, with the exception of two events in the 56-day sample. Below $530^{\circ} \mathrm{C}$ $\left(986^{\circ} \mathrm{F}\right)$, there was a large increase in weight loss with increasing curing time (Figures 7 and 14).

The change in low-temperature reactions with curing time is shown in Figure 7. There was a 0.58 weight $108 \mathrm{~s}$ below $530^{\circ} \mathrm{C}\left(986^{\circ} \mathrm{F}\right)$ in the unhycrated spent shale. After a 1-day cure, the weight loss increast. to 18. The two-week and eight-week sample colurns lost 48 of their initial weight. These reactions are not well understood; however, we suggest that water binds to the shale initially, and reaches a limit of -48 within the first 14 days. Weight loss between 100 and $250^{\circ} \mathrm{C}(212$ and $482^{\circ} \mathrm{F}$ ) decreased and the weight $108 \mathrm{~s}$ between 250 and $530^{\circ} \mathrm{C}(482$ and $986^{\circ} \mathrm{F}$ ) increased during the 14 th through 56 th days of curing (Figure 7). During this period, the water became more tightly bound to the shale.

We attribute the thermal events between 530 and $1000^{\circ} \mathrm{C}(986$ and $1832^{\circ} \mathrm{F}$ ) to the loss of tightly bound water and to the decomposition of dehydrated minerals because loosely bound water has already been removed as described above.

\section{Differential Thermal Analyses}

The unhydrated column and the 1-day, 208 water columns show no DTA peaks that can definitely be attributed to any exothermic or endothermic eventis. DTA evaluation of the 1-day, 308 water column; the 14-day, 308 water column; and the 17-day, 208 water column shows an exothermic event between 200 and $350^{\circ} \mathrm{C}\left(392\right.$ and $\left.662^{\circ} \mathrm{F}\right)$ in a $\mathrm{CO}_{2}$ atmosphere. The 1-day, 308 water column also shows an endothermic event between 250 and $425^{\circ} \mathrm{C}$ $\left(482\right.$ and $\left.797^{\circ} \mathrm{F}\right)$ in a nitrogen atmosphere.

There are several endothermic events that occur in all samples between 650 and $1000^{\circ} \mathrm{C}\left(1202\right.$ and $\left.1832^{\circ} \mathrm{F}\right)$. There is a sharp endothermic peak at $905^{\circ} \mathrm{C}\left(1661^{\circ} \mathrm{F}\right)$ in a $\mathrm{CO}_{2}$ atmosphere and a more gradual peak at $825^{\circ} \mathrm{C}\left(1517^{\circ} \mathrm{F}\right)$ in a nitrogen atmosphere. There are also endothermic 


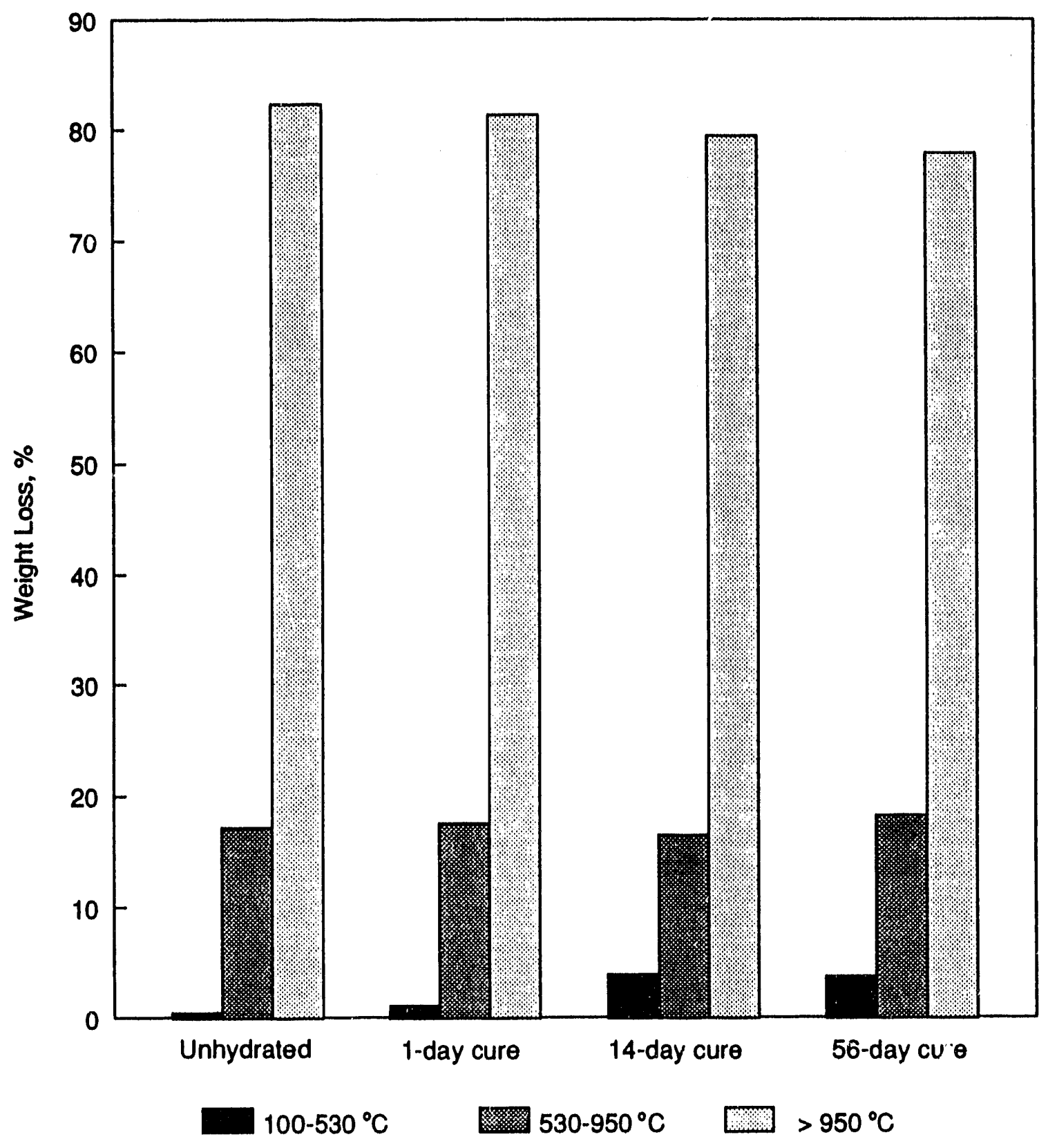

Figure 14. Total Weight Loss upon Heating for the 308 Water Columns 
peaks at $820^{\circ} \mathrm{C}\left(1508^{\circ} \mathrm{F}\right)$ and $760^{\circ} \mathrm{C}\left(1400^{\circ} \mathrm{F}\right)$ in a carbon dioxide atmosphere. These peaks are not noticeable in a nitrogen atmosphere. They may be present but, if so, they are hidden by the leading edge of the peak at $825^{\circ} \mathrm{C}\left(1517^{\circ} \mathrm{F}\right)$. There are two peaks that we detected only in the 56-day evaluations: an exothermic event at $920^{\circ} \mathrm{C}\left(1688^{\circ} \mathrm{F}\right)$ and an endothermic event at $710^{\circ} \mathrm{C}\left(1310^{\circ} \mathrm{F}\right)$.

Montmorillonite, vermiculite, and chlorite (Smykatz-Kloss 1974) and halloysite and kaolinite (Todor 1976) all exhibit similar thermal decomposition characteristics. Between 100 and $200^{\circ} \mathrm{C}\left(212\right.$ and $\left.392^{\circ} \mathrm{F}\right)$, they are characterized by an endothermic event with accompanying weight loss due to evaporation of water occupying the interlayer. Between 500 and $750^{\circ} \mathrm{C}\left(932\right.$ and $\left.1382^{\circ} \mathrm{F}\right)$ is a large endothermic event alsc accompanied by weight loss due to dehydroxylation (Todor 1976). Finally, between 825 and $1000^{\circ} \mathrm{C}\left(1517\right.$ and $\left.1832^{\circ} \mathrm{F}\right)$, there is a small exothermic event. This is attributed to the collapse of the clay's lattice structure and recrystalization of the dehydroxylated clay into a spinel-phase crystal (Smykatz-Kloss 1974).

In our study, the endothermic event at $710^{\circ} \mathrm{C}\left(1310^{\circ} \mathrm{F}\right)$ and the exothermic event at $920^{\circ} \mathrm{C}\left(1688^{\circ} \mathrm{F}\right)$ of the 56 -day sample in a nitrogen atmosphere (Figure 11) suggest that a hydroxylated clay-like mineral has formed between day 14 and day 56. Unfortunately, the decomposition of $\mathrm{CO}_{3}{ }^{2-}$ masks the dehydroxylation of hydroxylated silicate minerals and reduces our interpretative ability.

The large peaks at $825^{\circ} \mathrm{C}\left(1517^{\circ} \mathrm{F}\right)$ in a nitrogen atmosphere and at $905^{\circ} \mathrm{C}\left(1661^{\circ} \mathrm{F}\right)$ in a carbon dioxide atmosphere have the shape change and peak shift caused by different atmospheres typical of simple, anhydrous carbonates (Warne 1980). These peaks are substantially smaller for the samples with longer cure times, thus, suggesting that the source of these peaks decomposes with time. It seems likely that this material is $\mathrm{CaCO}_{3}$.

The amount of $\mathrm{CaCO}_{3}$ decreases with increasing curing time. This is based on two trends over the temperatures at which these large endotherms occur. The endotherms in the DTA curves show progressively smaller magnitudes with increasing curing times in both the nitrogen and the carbon dioxide atmospheres. Also, there is progressively less weight loss with increasing cure time in a carbon dioxide atmosphere between 890 and $940^{\circ} \mathrm{C}\left(1634\right.$ and $\left.1724^{\circ} \mathrm{F}\right)$. This suggests that $\mathrm{CaCO}_{3}$ is solubilizing, and $\mathrm{Ca}$ is possibly reacting with $\mathrm{SiO}_{2}$ and $\mathrm{Al}$ compounds to form cementitious materials. 


\section{CONCIUSIONS}

Results of this study show that there are changes in the chemical properties of the hydrated spent shale dependent on water content and cure time. Mineral-phase changes are evident in XRD and SEM/EDXA analyses. X-ray diffraction data were analyzed for changes in mineralogy over a period of increasing compressive strength. The XRD data show no increase in the amount of calcite with an increase in cure time. This evidence suggests that the cement is not in the form of calcite. Also, we could not positively identify anhydrite; however, minor amounts of gypsum were detected in all but the 56-day sample. The amount of periclase also decreases with increasing cure time. The dissolution products of periclase, calcite, and gypsum undoubtedly contribute to the formation of the cementitious material. An unidentified peak at $19.7^{\circ}$ $2 \theta$, detected in the unhydrated spent shale, was not evident in the hydrated samples. It is very likely that this unidentified mineral is also instrumental in the cementation process and needs to be studied further. The spent shale was magnetic; however, a Fe mineral phase could not be identified with XRD.

Scanning electron microscopy revealed that with an increase in compressive strength there is also an increase in bridging between particles of spent shale. Marcus et al. (1985) also report that the growth of crystallite bridges between particles correlate to an increase in cementation. Elemental analysis, with the energy dispersive $x-r a y$ analyzer, identified $\mathrm{Mg}, \mathrm{Al}, \mathrm{Si}, \mathrm{K}, \mathrm{Ca}$, and $\mathrm{Fe}$ as the major elements present in all of the samples. Calcium was the major element identified in the bridging material. Because the concentrations of bridging material were relatively low in the samples we examined, the EDXA spectra we obtained could have shown constituents from the surrounding material. We identified sulfur as a main element along with $\mathrm{Mg}, \mathrm{Si}$, and $\mathrm{Ca}$ in clusters of rod-like crystals. Marcus et al. (1985) identified these rods as another form of cementing material. The rods increase in size and number with the increase in cure time. From this evidence, we can conclude that the rod-like crystals contribute to the cementing nf the material.

Differential thermal analyses and thermogravimetric analyses were performed to correlate compressive strength gain with thermal alterations. The initial incorporation of water into the structure of the spent shale was completed during the first 14 days of curing. This is demonstrated by the constant weight loss between 100 and $530^{\circ} \mathrm{C}(212$ and $986^{\circ} \mathrm{F}$ ) after 14 and 56 days of curing. There were significant changes in the thermal curves of the 14-and 56-day samples. First, there was a shift from a low-to medium-temperature weight $10 \mathrm{ss}\left(100-250^{\circ} \mathrm{C}\right.$ to $250-530^{\circ} \mathrm{C} / 212-482^{\circ} \mathrm{F}$ to $\left.482-/ 986^{\circ} \mathrm{F}\right)$. We suggest that this shift is caused by changes in the structure of water present in the spent shale. Second, we detected significant changes in the 56-day sample. An endothermic event occurred at $710^{\circ} \mathrm{C}\left(1310^{\circ} \mathrm{F}\right)$ that is characteristic of the dehydroxylation of a number of clay minerals (Todor 1976). Also, an exothermic event occurred at $920^{\circ} \mathrm{C}\left(1688^{\circ} \mathrm{F}\right)$ that is characteristic of the collapse of the clay's lattice structure and subsequent recrystallization into a spinel phase (Smykatz-Kloss 1974). This evidence suggests that formation of a hydrated, clay-like mineral occurred in the 56-day sample. 


\section{RECOMDENDATIONS}

Quantification of the cementing material in the hydrated lurgi spent oil shale will require additional analyses. Evaluations using electronprobe microanalysis (EPMA), nuclear magnetic resonance (NMR), and transmission electron microscopy (TEM) may show us more on the composition of the cementing materials. other analytical procedures such as selective dissolution in combination with XRD and EDXA may prove to be important tools that will provide additional information of the composition of the cementing materials. 
This work was gupported by the U.S. Department of Energy under Cooperative Agreement DE-FC21-86MC110\%. We would like to thank Dr. John rurner and the University of Wyoming Department of Civil Engineering and the lysimeter group of the Department of Range Management. We would like th thank Dr. Susan swapp of the University of Wyoming, Department of Geology and Geophysics for her helpful ideas and suggestions. We also want to thank Brian Hart and Nancy Nigg for their analytical work on the leachates.

\section{DISCIAIMER}

Any mention of particular instrument brand names or models of equipment is for information only and does not imply endorsement. 


\section{REFERENCES}

Bentur, A., and T. Grinberg, 1982, Hydration and Properties of Pastes and Mortars made with oil shale Ash. Ceramic Bulletin, 61(12): $1296-1300$.

Dollimore, D., A. Dyer, G.A. Gamlen, and C.A.C. Kang, 1981, Heat Treatment of zirconia-silica waste Material, in Dollimore, D., ed., Proceedings of the second European symposium on Thermal Analysis. Heyden \& Son, Philadelphia, PA, 387-390.

Essington, M.E., 1989, The Composition and solubility of Ettringite Precipitated from Combusted oil shale. Laramie, WY, DOE Report $\mathrm{DOE} / \mathrm{MC} / 11076-2943$.

Glasser, F.P., 1983, Reactions Occurring During Cement Making, in Barnes, P., ed., structure and Performance of Cements. Applied Science Publishers, New York, NY, 69-108.

Gonzalez-Calbet, J.M., and M.A. Alario Frarco, 1981, The Vacuum Thermal Decomposition of synthetic BFeOH, in Dollimore, D., ed., Proceedings of the second European Symposium on Thermal Analysis. Heyden \& Sons, Philadelphia, PA, 404-407.

Hendrickson, T.A., ed., 1975, synthetic Fuelg Data Handbook, Cameron Engineers, Denver, CO, 305 p. 41.

Horsley, S.E., and D.V. Nowe1l, 1981, The Dehydration of a-zirconium Phosphate, in Dollimore, D., ed., proceedings of the Second European Symposium on Thermal Analysis. Heyden sons, Philadelphia, PA, 443-445.

Marcus, D., D.A. Sangrey, and S.A. Miller, 1985, Effects of Cementation process on spent shale stabilization. Transactions of society of Mining Engineers, 287: 1225-1232.

Marino, O., and G. Mascolo, 1981, Thermal stability of Mg,Al Double Hydroxides Variously Anion Exchanged, in Dollimore, D., ed., Proceedings of the Second European symposium on Thermal Analysis. Heyden \& Sons, Philadelphia, PA, 391-394.

Mousty, H., A. Abou-Kais, N. Nasrallah-Abou Kais, z. Gabeli.ca, and E.G. Derouane, 1981, Thermal Decomposition of Potassium Ferrocyanide Under a Reducing Atmosphere, in Dollimore, D., ed., proceedings of the second European symposium on Thermal Analysig. Heyden \& Sons, Philadelphia, PA, 449-452.

Perkin-Elmer, 1989a, The Perkin-Elmer PC Series Thermal Analysis system: DTA 1700 High Temperature Differential Thermal Analyzer operator's Manual. Perkin-Elmer, Norwalk, CT.

Perkin-Elmer, $1989 \mathrm{~b}$, The Perkin-Elmer PC Series, Thermal Analysis system: TGA 7 Thermogravimetric Analyzer operator's Manual. Perkin-Elmer, Norwalk, CT. 
Roessler, M., and I. Odler, 1981, studies on Non-Hydrated portland Cements by Differential Thermal Analysia, in Dollimore, D., ed., Proceedings of the Second European symposium on Thermal Analysig. Heyden \& Sons, Philadelphia, PA,

Rothwell, R.A., 1989, Initial Geotechnical Properties of a Retorted and Combusted oil shale solid Waste, Master's Thesis, University of Wyoming, Laramie, WY, $168 \mathrm{p}$.

Schmalfeld, I.P., 1975, The Use of the Lurgi-Ruhrgas Process for the Distillation of oil shale. Quarterly of the colorado school of Mines, Golden, Co, 70: 129-145.

Smykatz-Kloss, W., 1974, Differential Thermal Analysis: Applications and Resultg in Mineralogy, Springer-Verlag, New York, NY, 185 p.

Soiltest, 1964, Operating Instructions for Harvard Miniature Apparatus, Evanston, IL, 3 .

Stacey, M.H., 1981, The Kinetics and Reaction Mechanism of Hydrozincite Thermal Decomposition, in Dollimore, D., ed., proceedings of the Second European symposium on Thermal Analysis. Heyden \& sons, Philadelphia, PA, 408-412.

Todor, D.N., 1976, Thermal Analysis of Minerals. Abacus Press, Tunbridge Wells, Kent, England, 106-111.

Turner, J.P., and R.A. Rothwell, 1991, Geotechnical Properties of Combusted Western oil shale, Environmental Geology and Water Sciences, in press.

Warne, s. st.J., 1980, Predictable Curve Modifications and Variable Atmosphere DTA: Uses in Diagnostic Mineralogy, Particularly for Carbonates, in Hemminger, H., ed., International conference on Thermal Analysis, 6th: 1980: Bayreuth, Germany. Birkhauser Verlag, Boston, MA, 283-288.

Welton, J.E., 1984, SEM Petrology Atlas. The American Asgociation of Petroleum Geologists, Tulsa, OK, 157 p. 
APPENDIX A

X-ray Diffractograms of the Unhydrated and Aydrated Lurgi spent Oil shales 


\section{CONTENTS OF APPENDIX A}

Page

X-ray Diffractogram of Unhydrated Lurgi spent oil shale 2-170 20... 31

X-ray Diffractogram of Hydrated Lurgi spent oll shale,

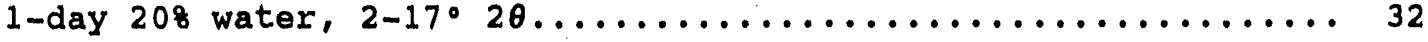

X-ray Diffractogram of Hydrated Lurgi spent oil shale,

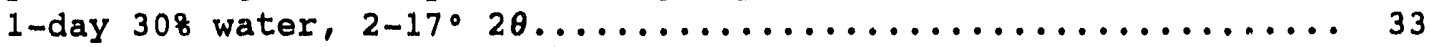

$x$-ray Diffractogram of Hydrated Lurgi spent oil shale,

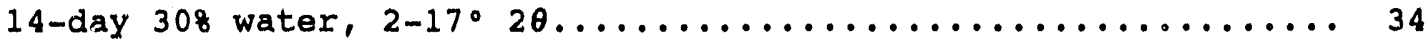

$x$-ray Diffractogram of Hydrated Lurgi spent oll shale,

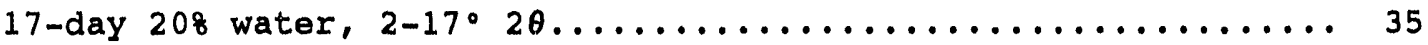

X-ray Diffractogram of Hydrated Lurgi spent oil shale,

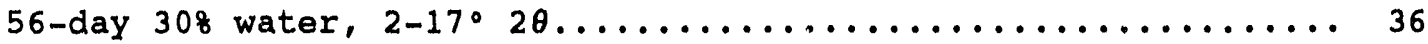

X-ray Diffractogram of Unhydrated Lurgi spent oil shale, 17-32॰20.. 37

X-ray Diffractogram of Hydrated Lurgi spent oil shale,

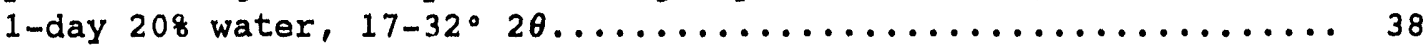

X-ray Diffractogram of Hydrated Lurgi spent Oil shale,

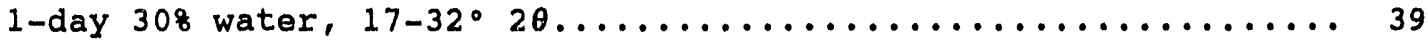

X-ray Diffractogram of Hydrated Lurgi spent oil shale,

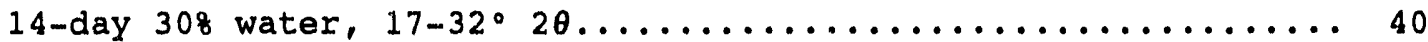

X-ray Diffractogram of Hydrated Lurgi spent Oil shale, 17-day 208 water, $17-32^{\circ} 20 \ldots \ldots \ldots \ldots \ldots \ldots \ldots \ldots \ldots \ldots \ldots \ldots \ldots \ldots \ldots . \ldots \ldots \ldots$

X-ray Diffractogram of Hydrated Lurgi spent oll shale,

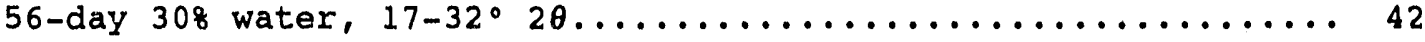

X-ray Diffractogram of Unhydrated Lurgi Spent oil shale, 32-47०20..43

X-ray Diffractogram of Hydrated Lurgi spent oil shale,

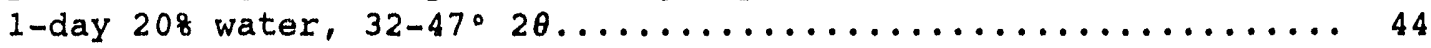

X-ray Diffractogram of Hydrated Lurgi spent oil shale,

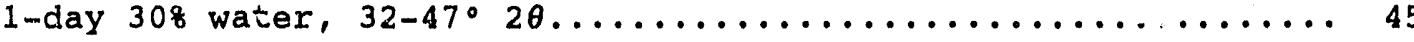




\section{CONTENTS OF APPENDIX A (continued)}

\section{Page}

X-ray Diffractogram of Hydrated Lurgi spent oll shale,

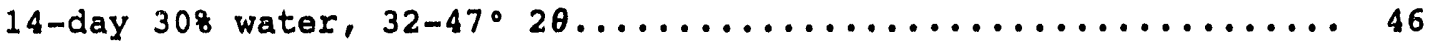

X-ray Diffractogram of Hydrated Lurgi spent oll shale,

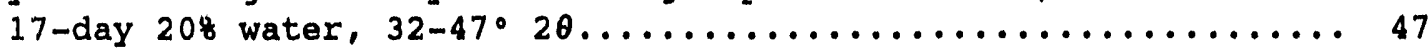

X-ray Diffractogram of Hydrated Lurgi spent oil siale,

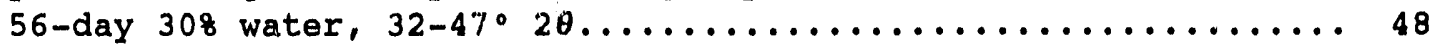

X-ray Diffractogram of Unhydrated Lurgi spent oil shale, 47-62。 20.. 49

X-ray Diffractogram of Hydrated Lurgi spent oil shale,

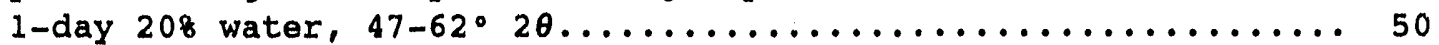

X-ray Diffractogram of Hydrated Lurgi spent oil shale,

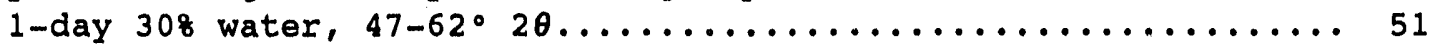

X-ray Diffractogram of Hydrated Lurgi spent oil shale,

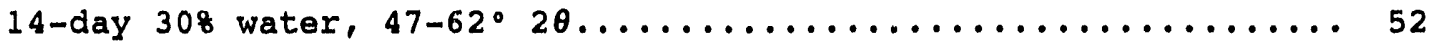

X-ray Diffractogram of Hydratied Lurgi spent oil shale,

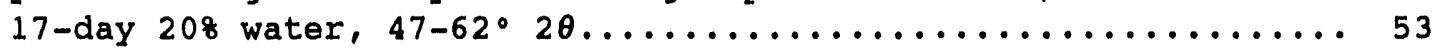

$X$-ray Diffractogram of Hydrated Lurgi spent oil shale,

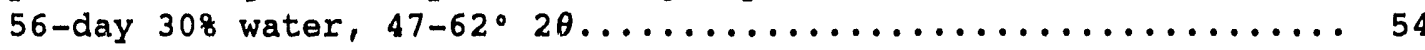




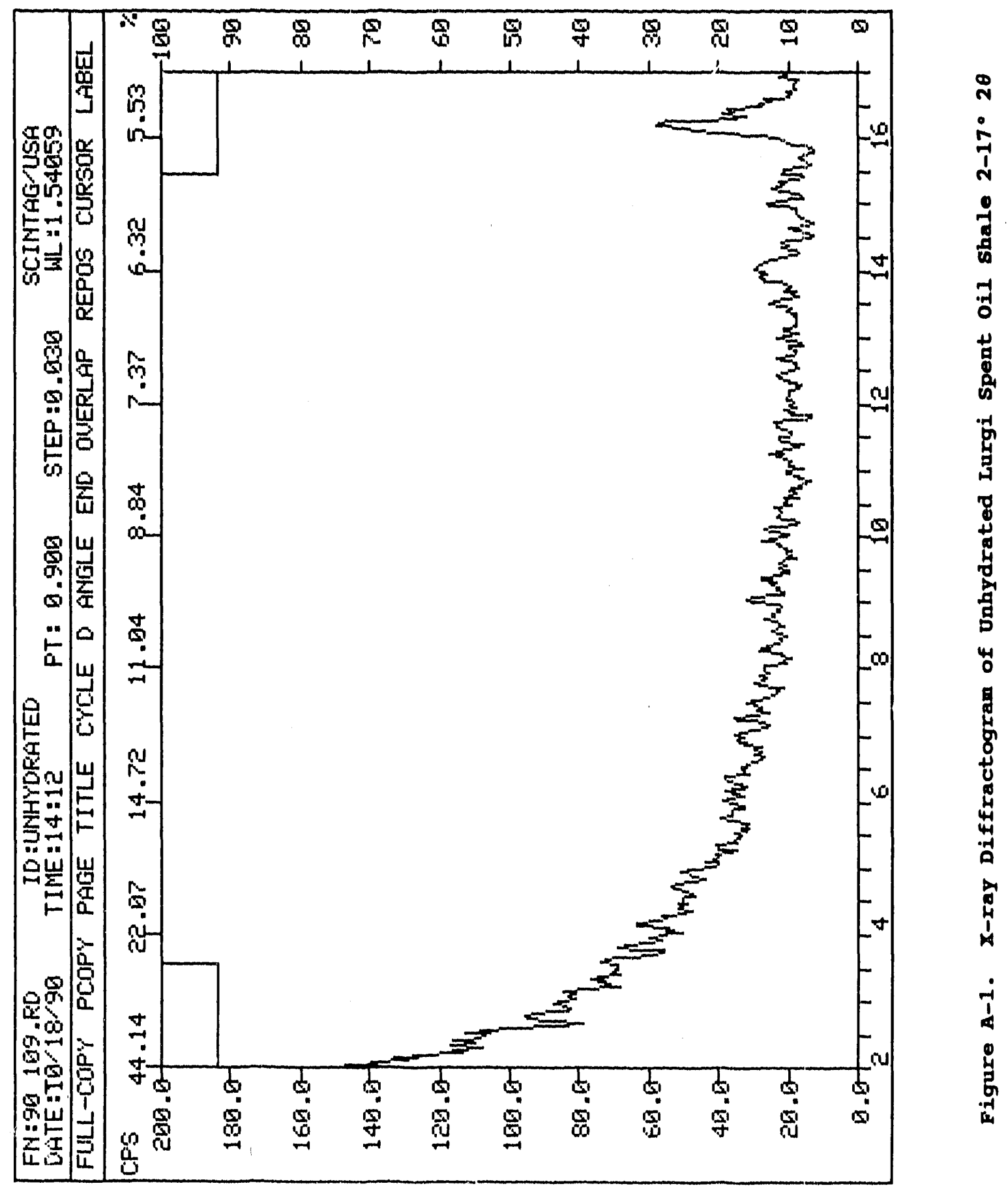




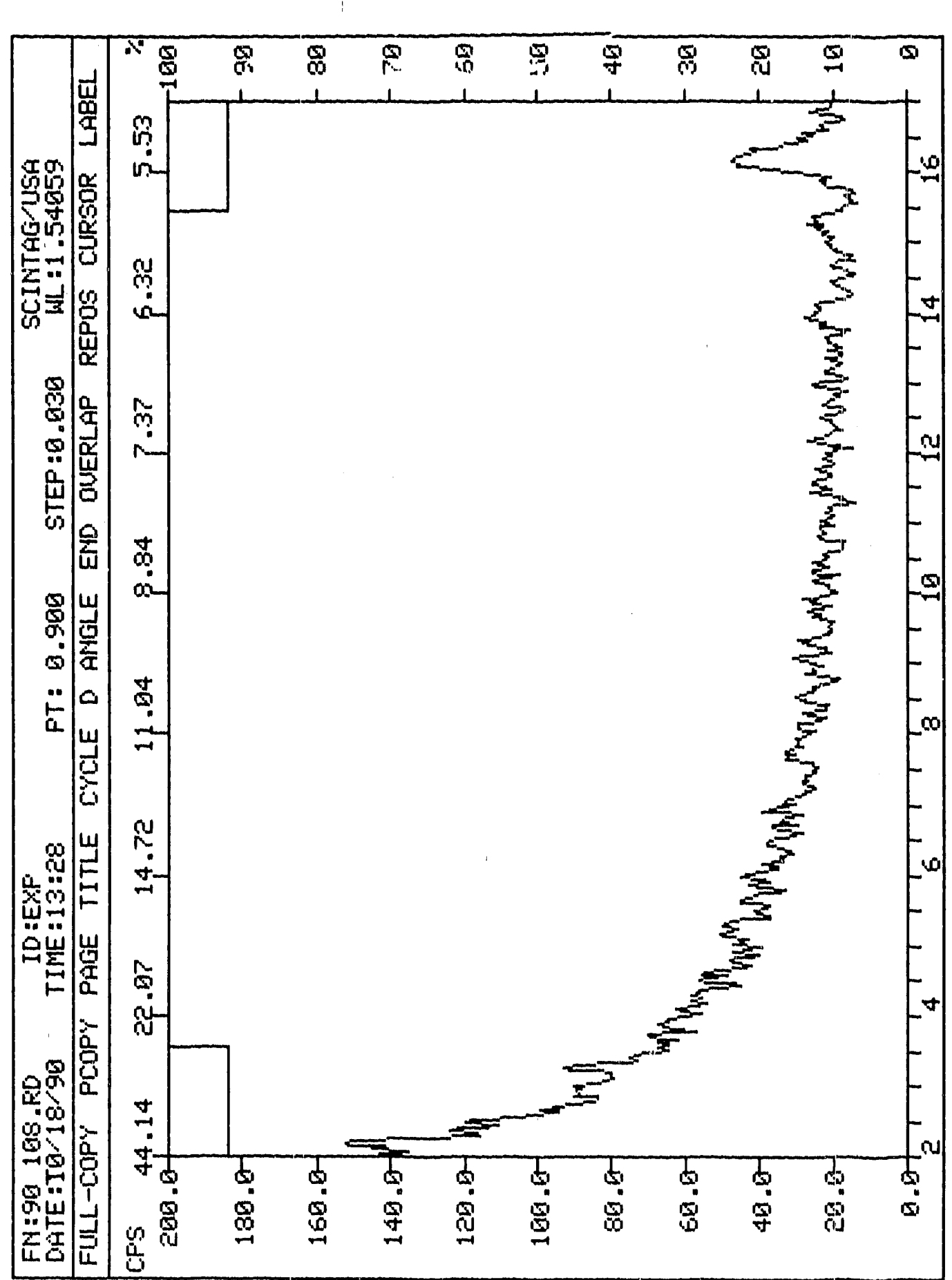

D 


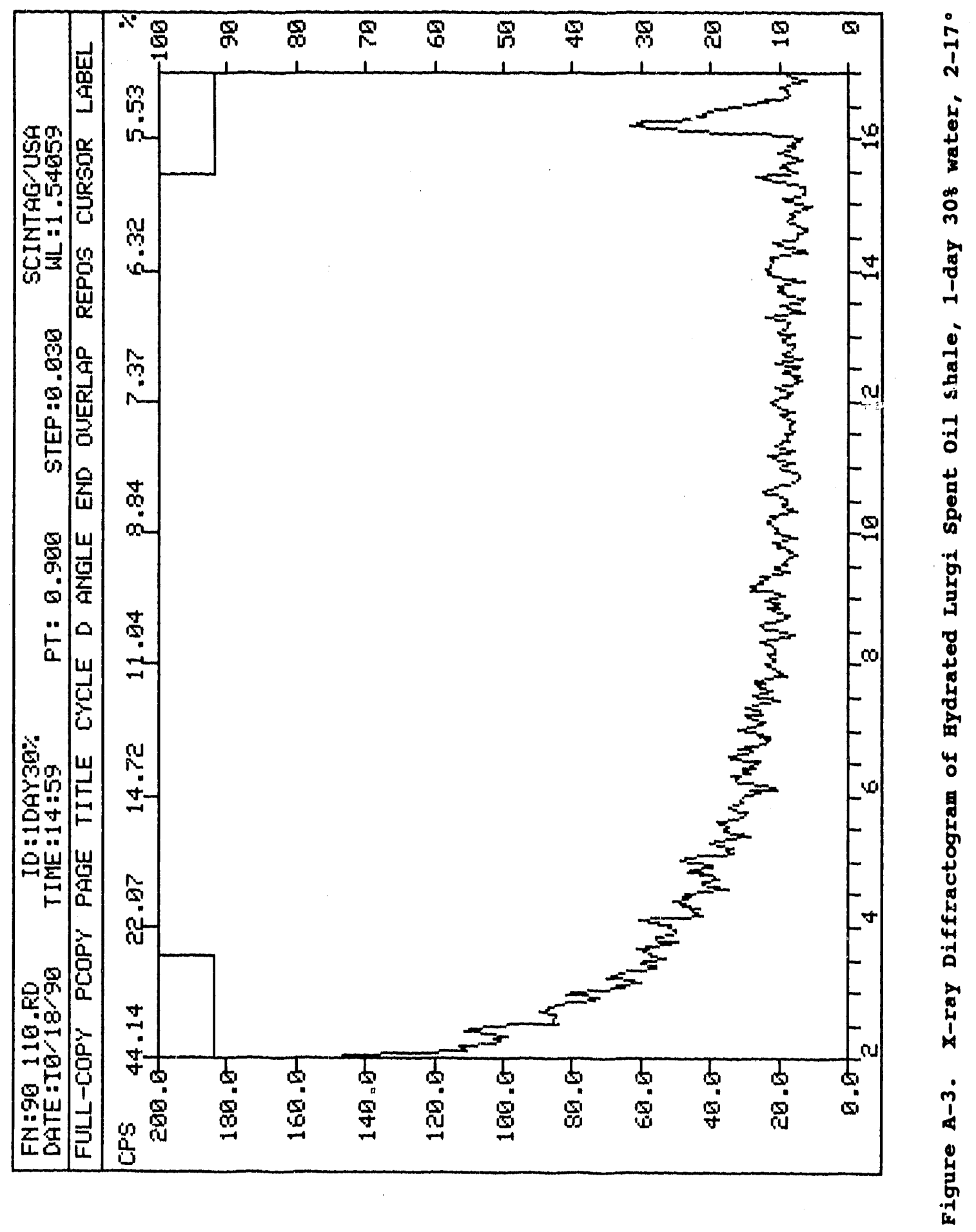




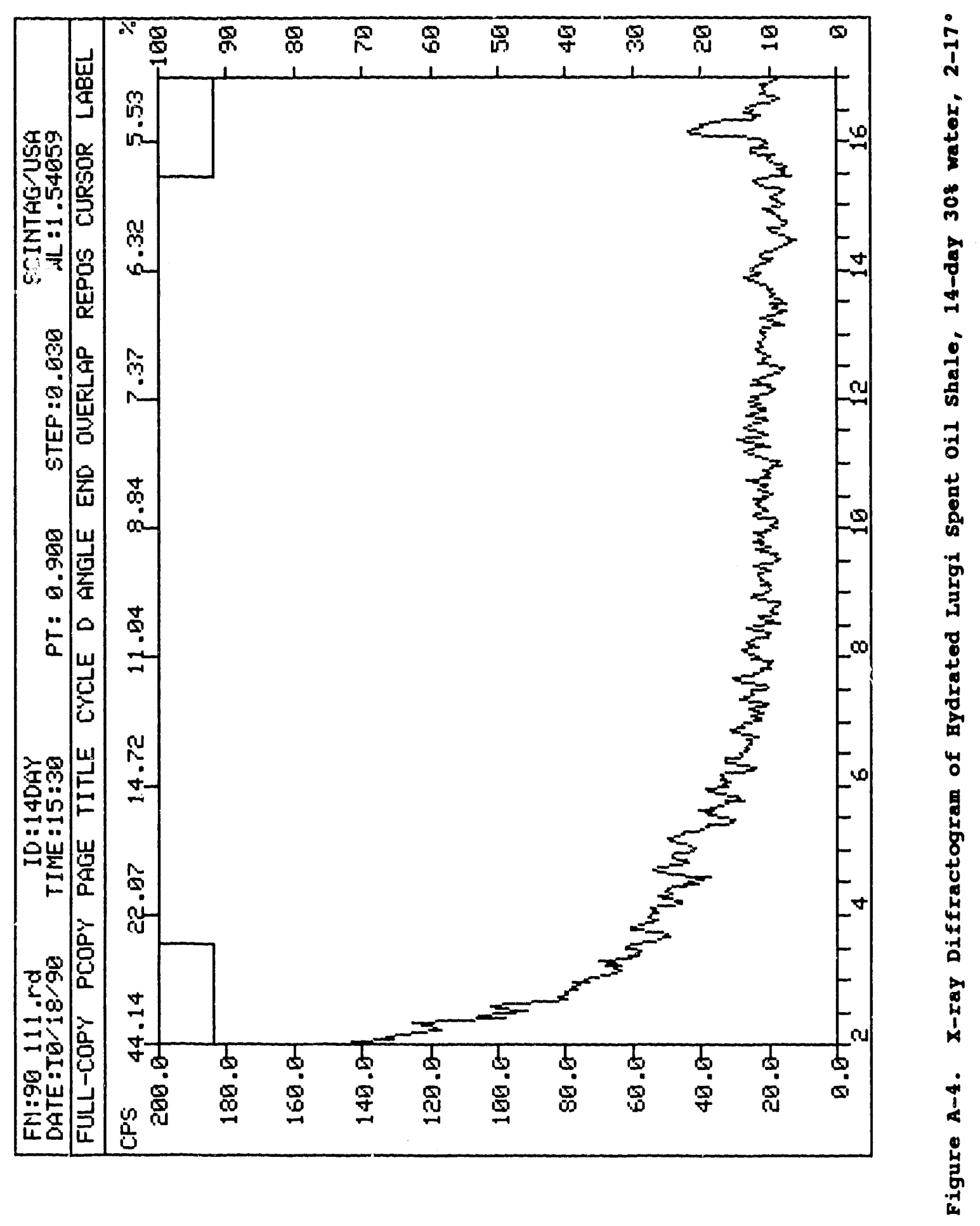




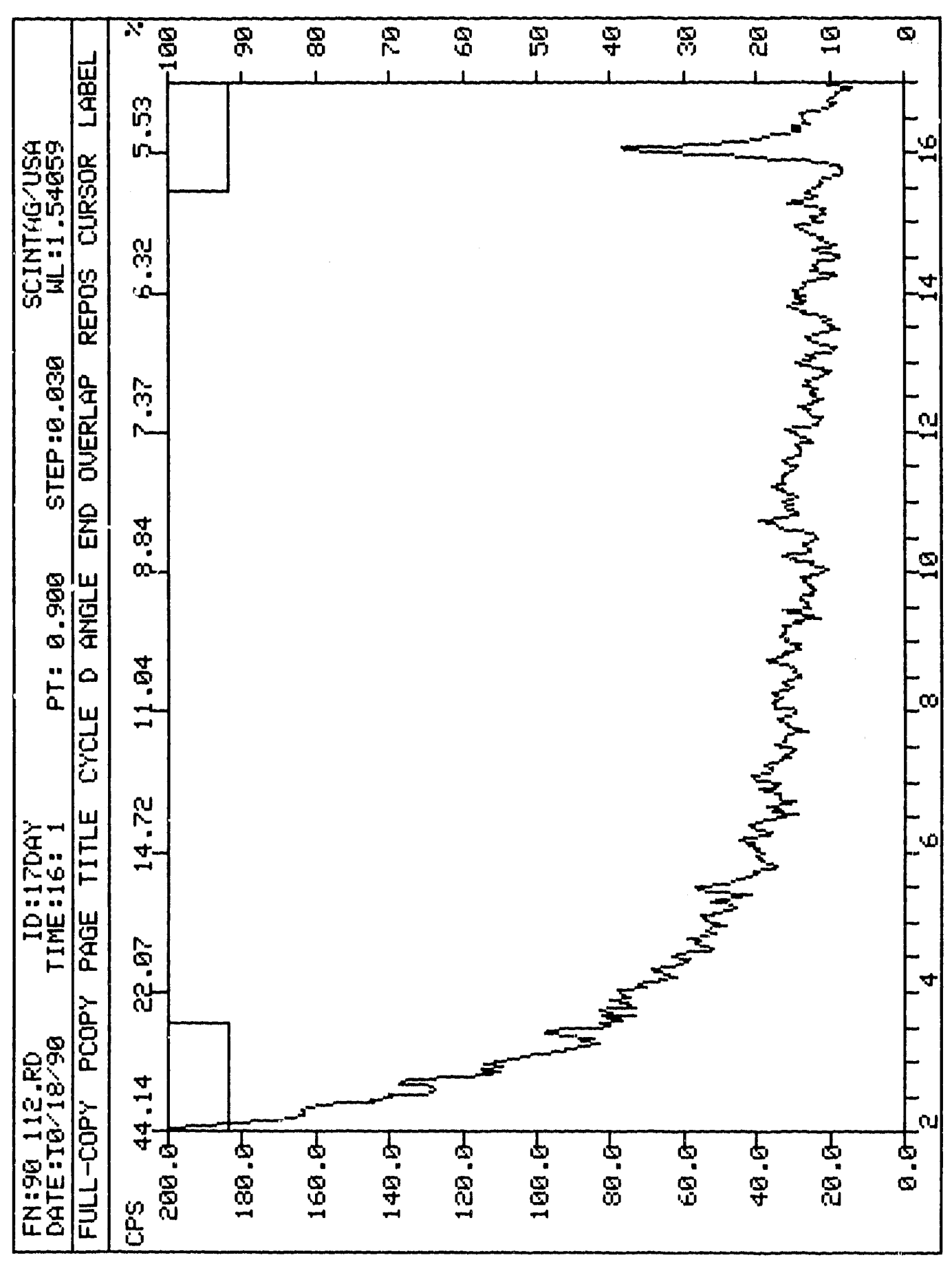

D 


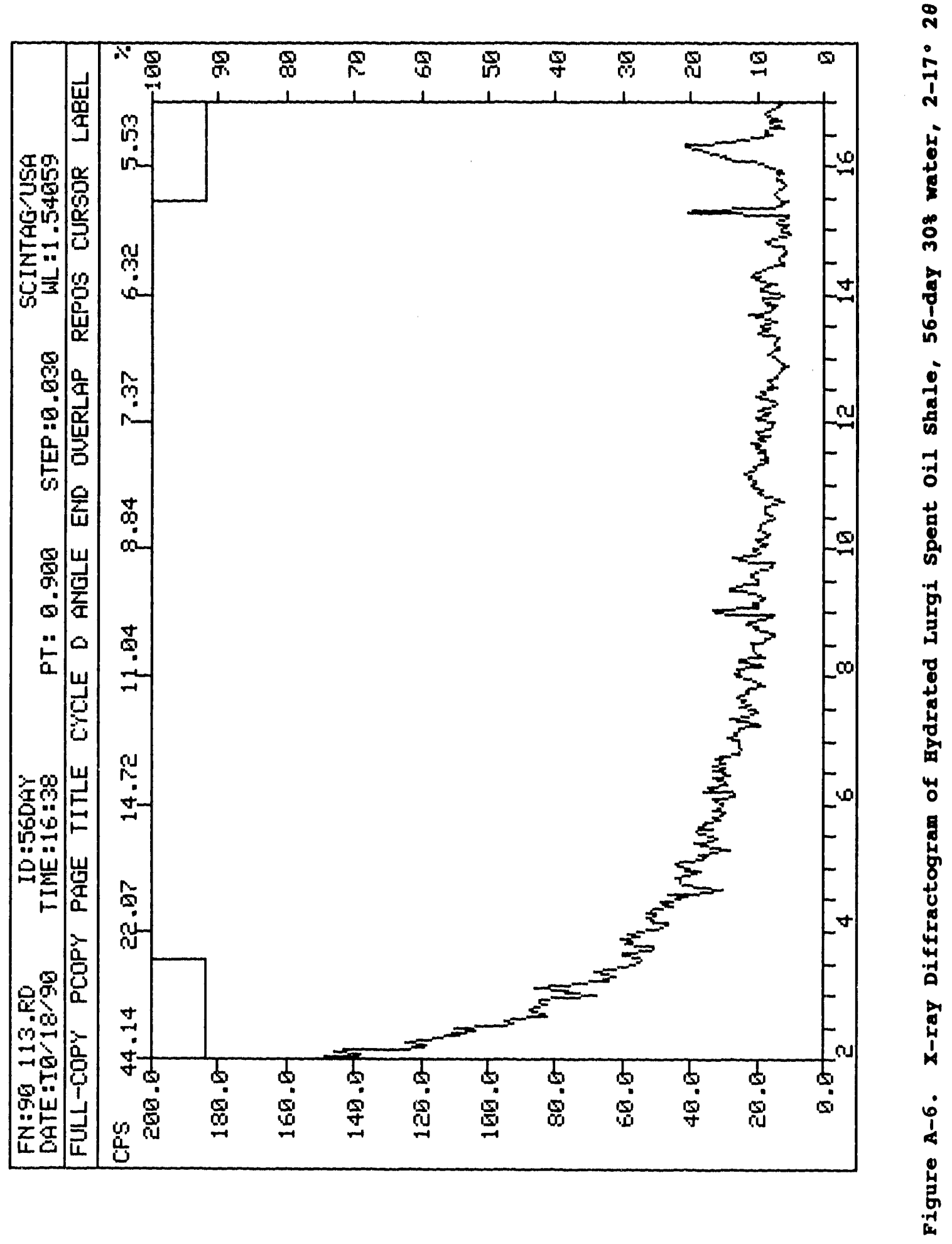




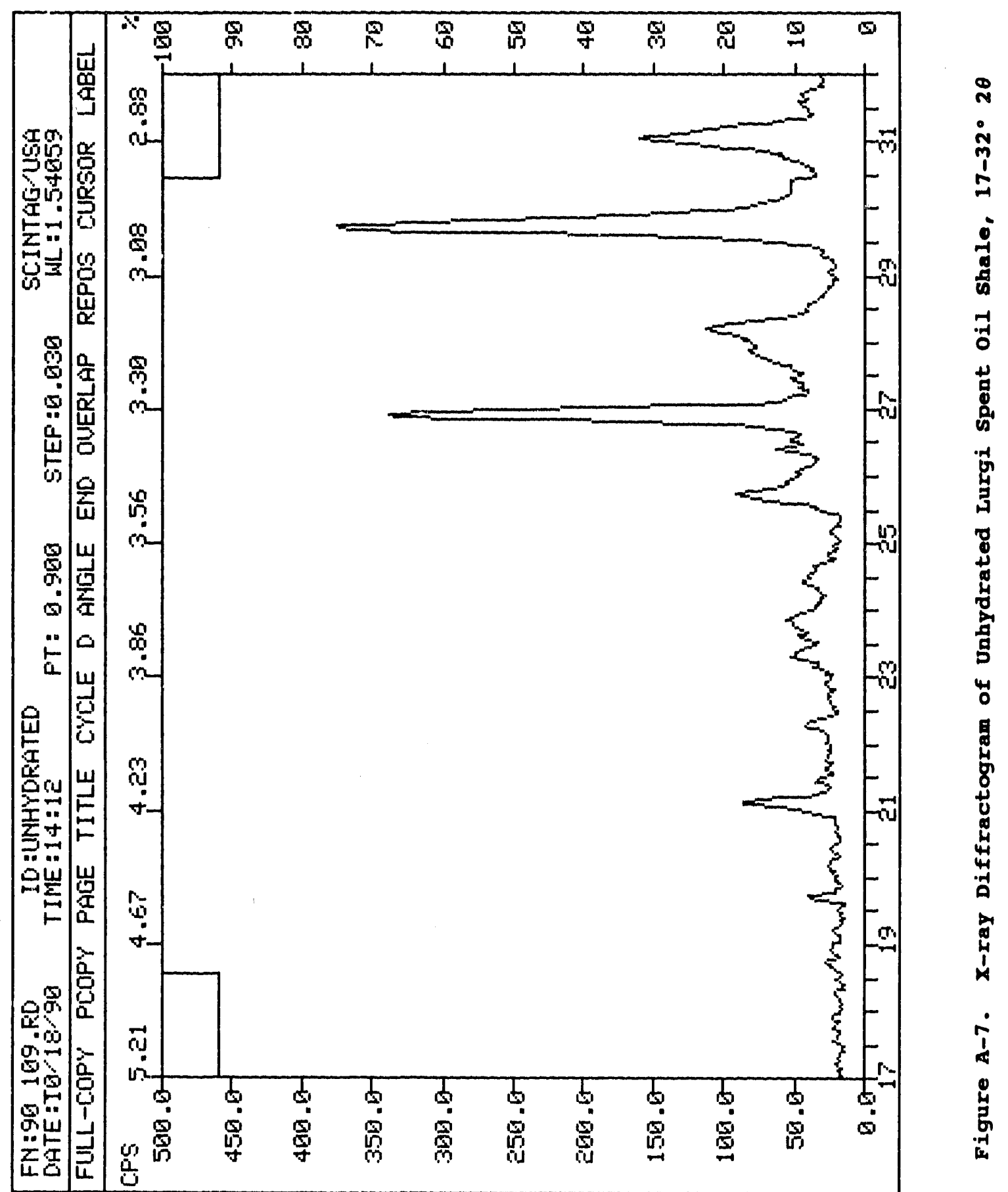




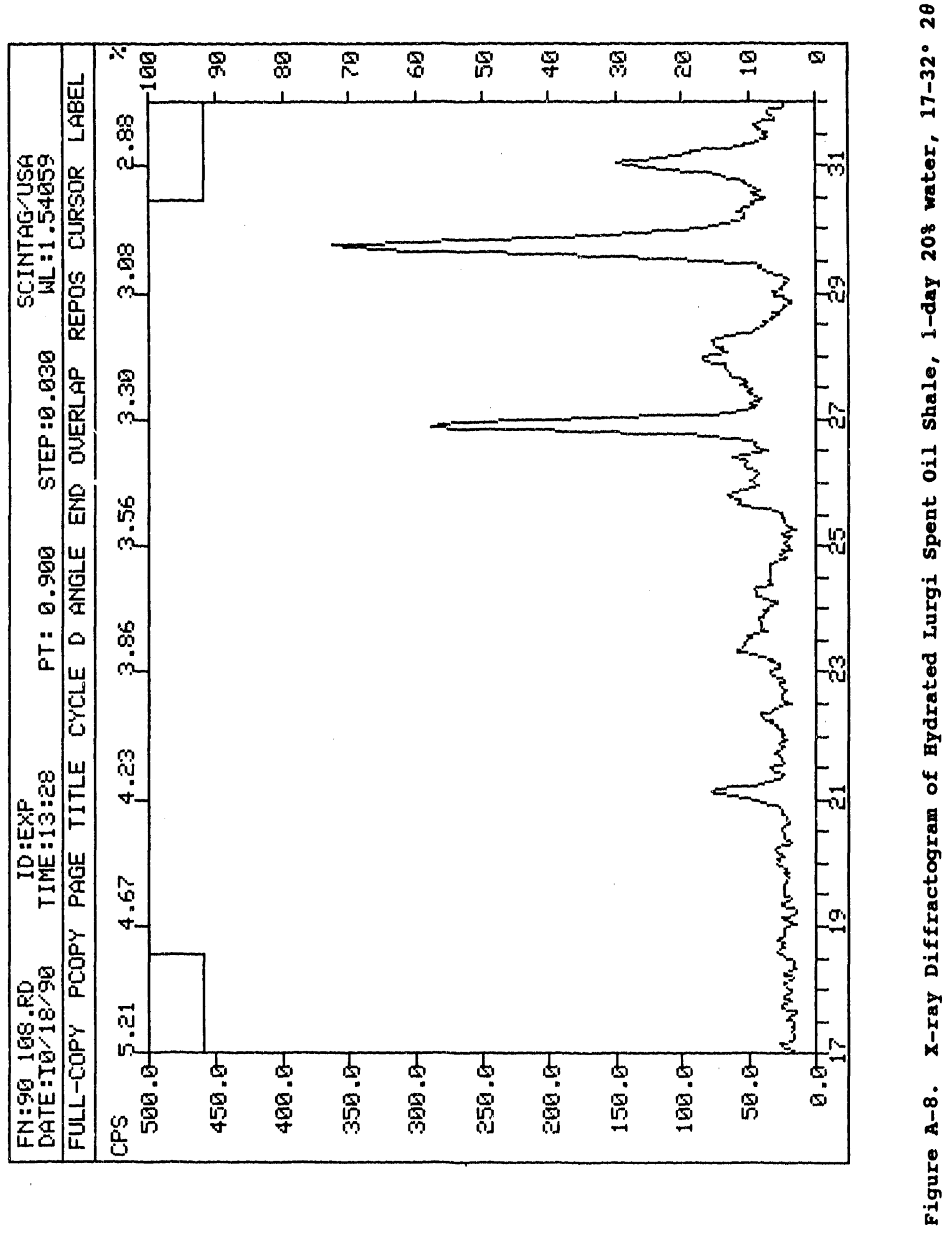




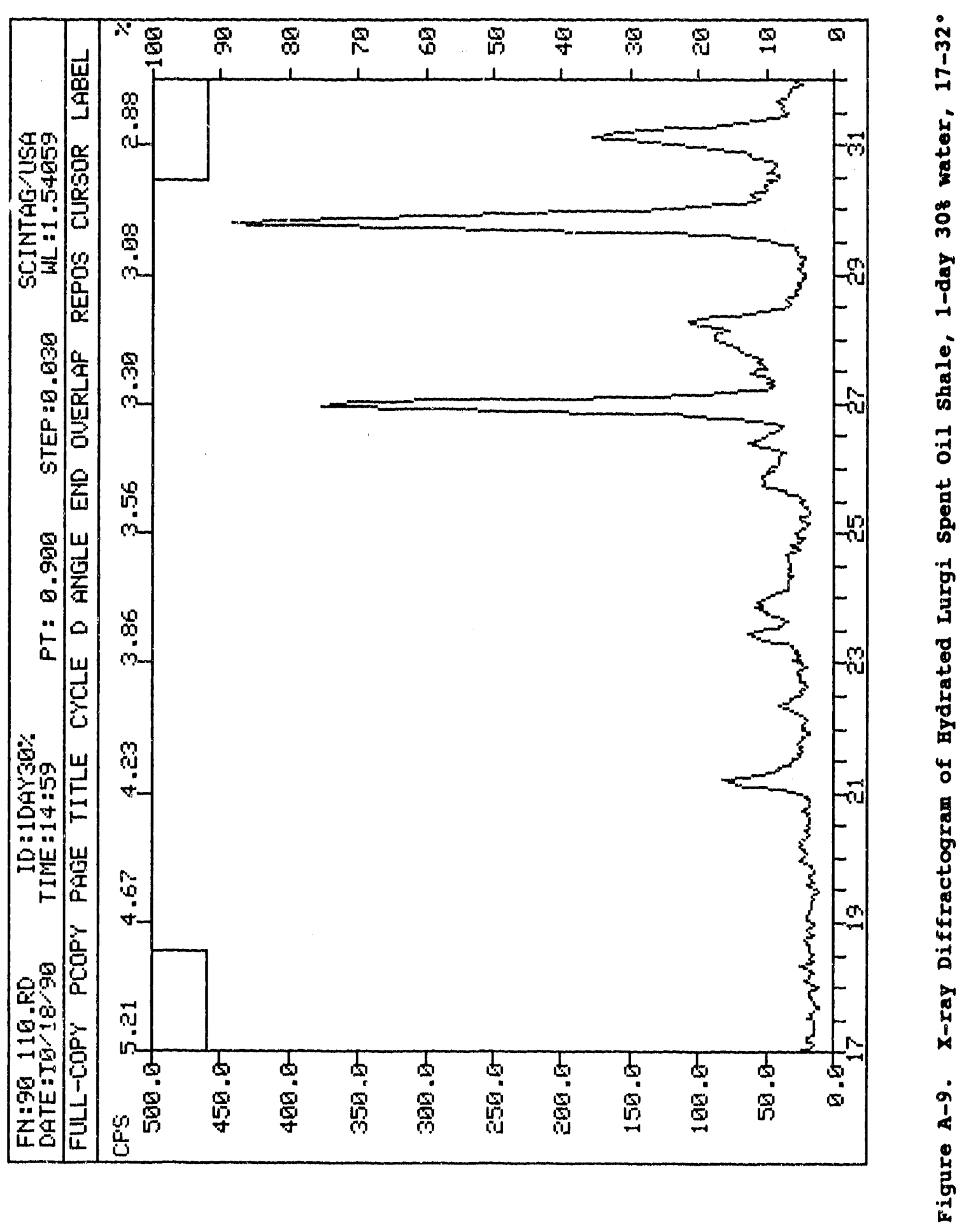




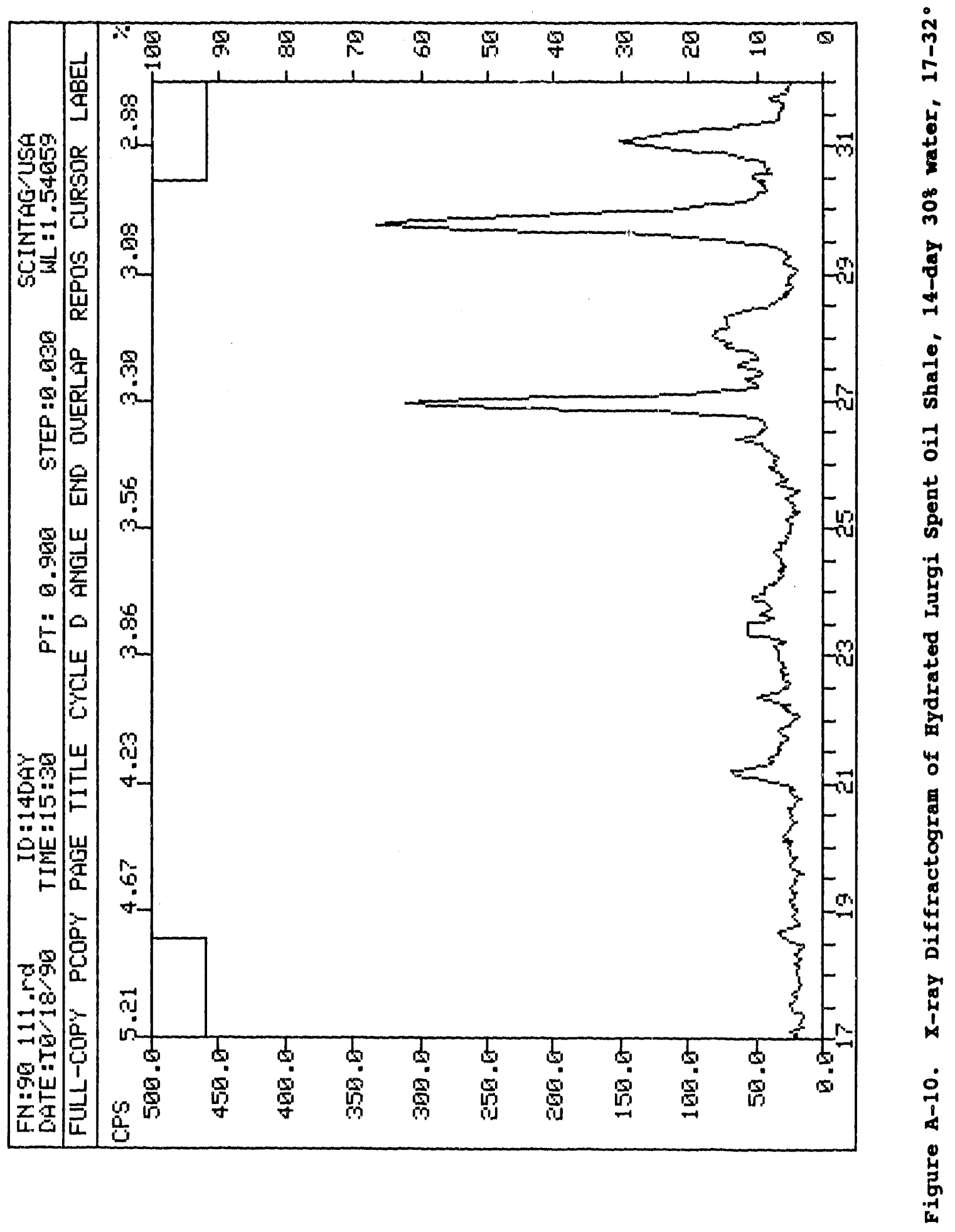






N

$\stackrel{0}{\mathfrak{n}}$

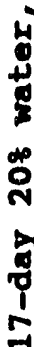

章

-7

㟔

占

。

0

曷

年 


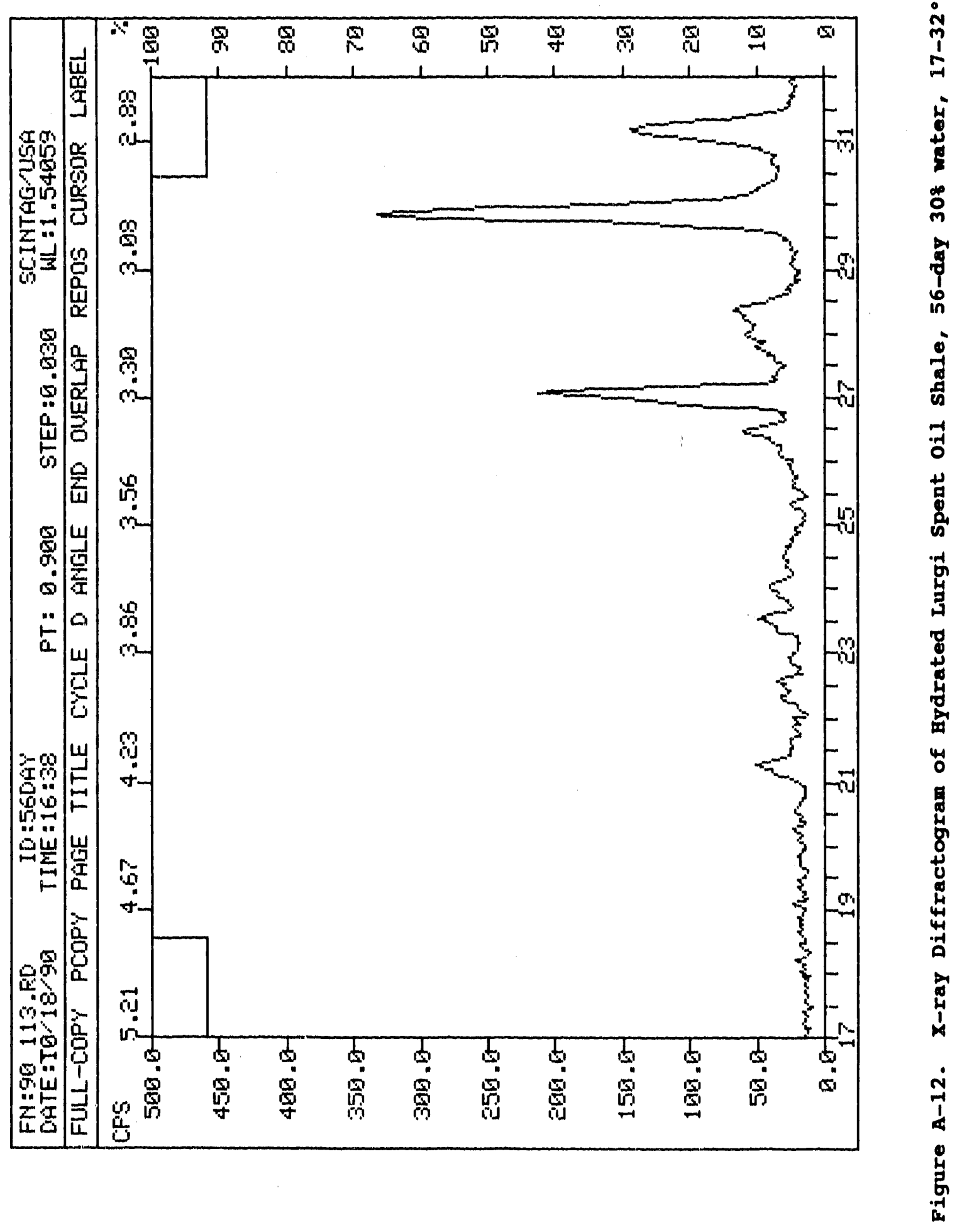




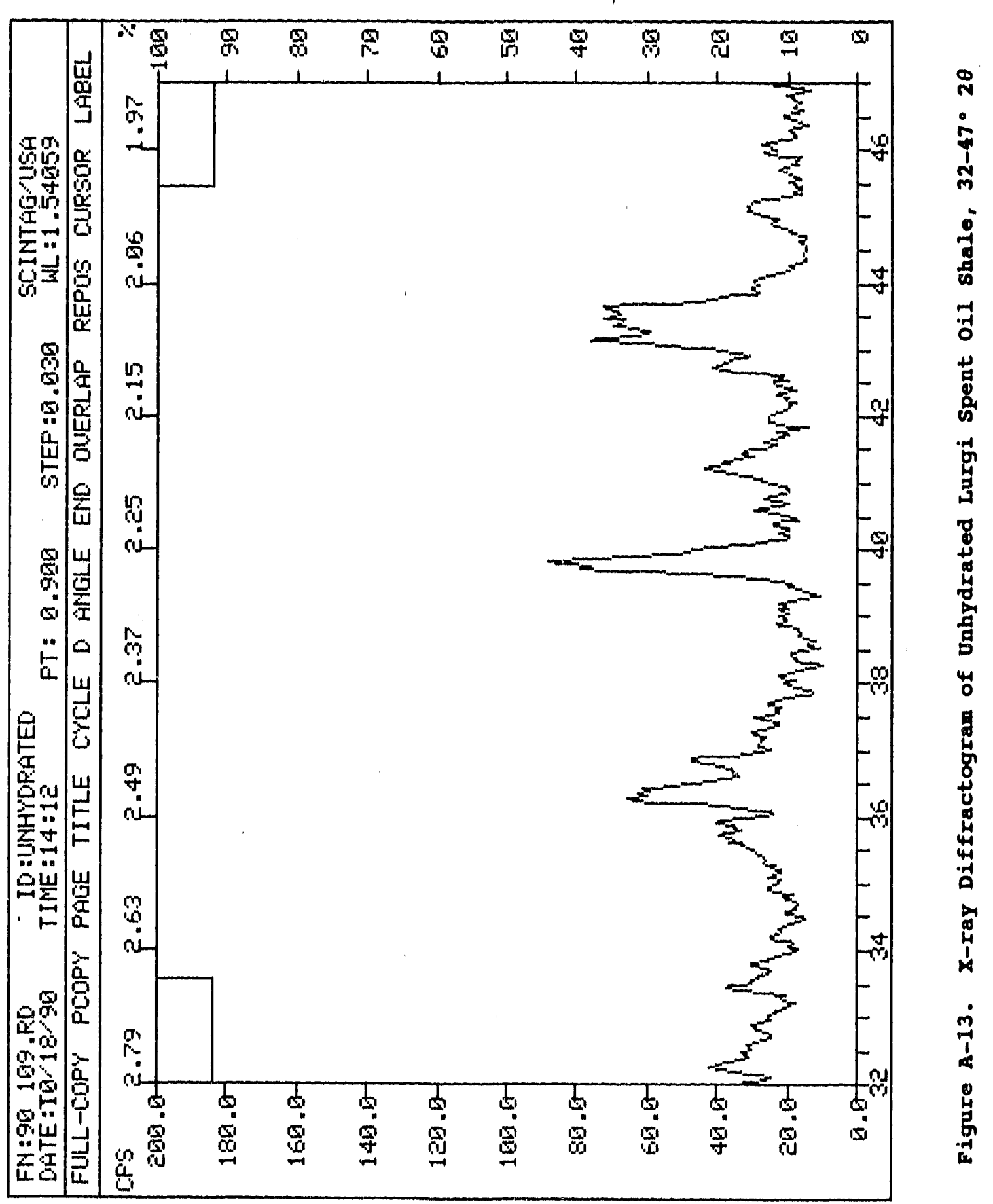




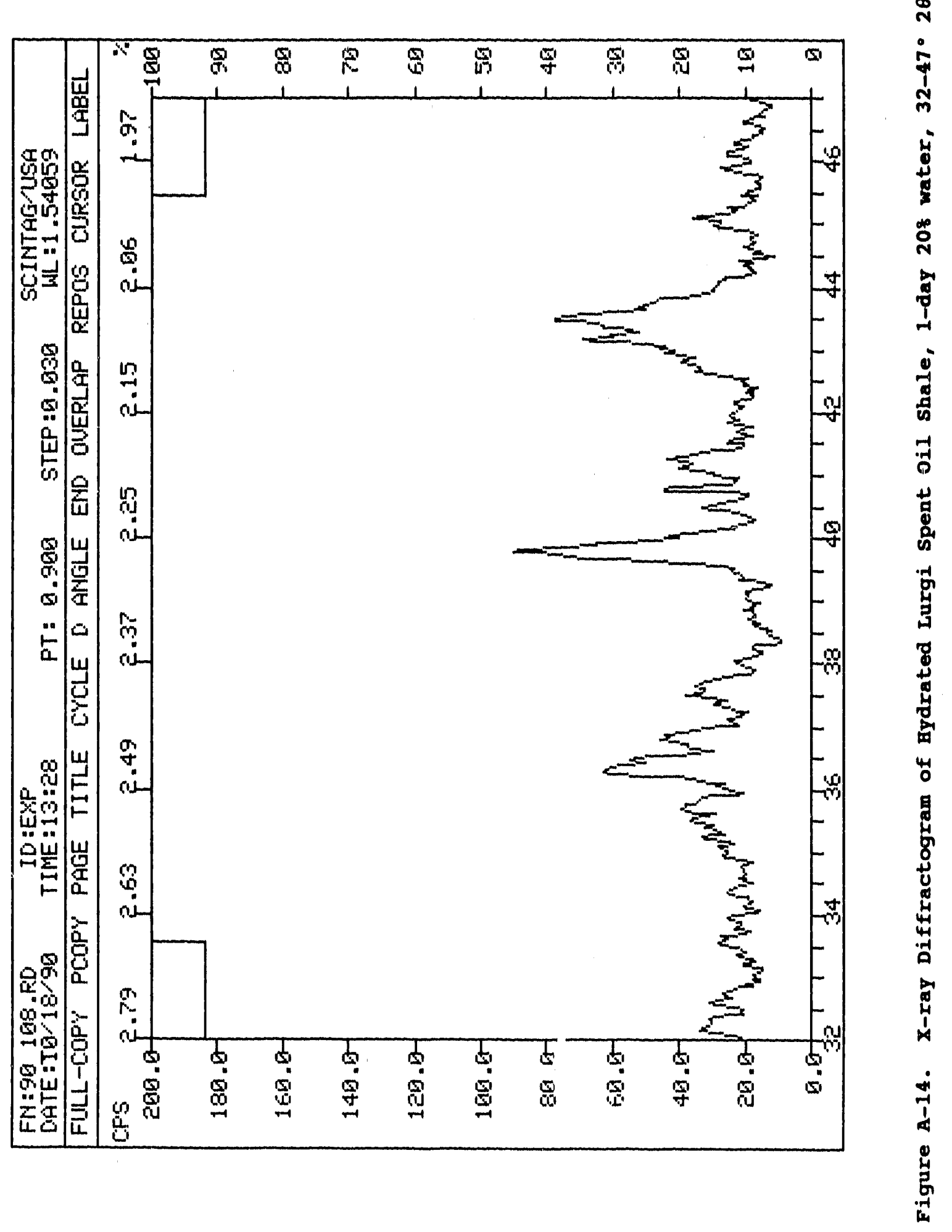




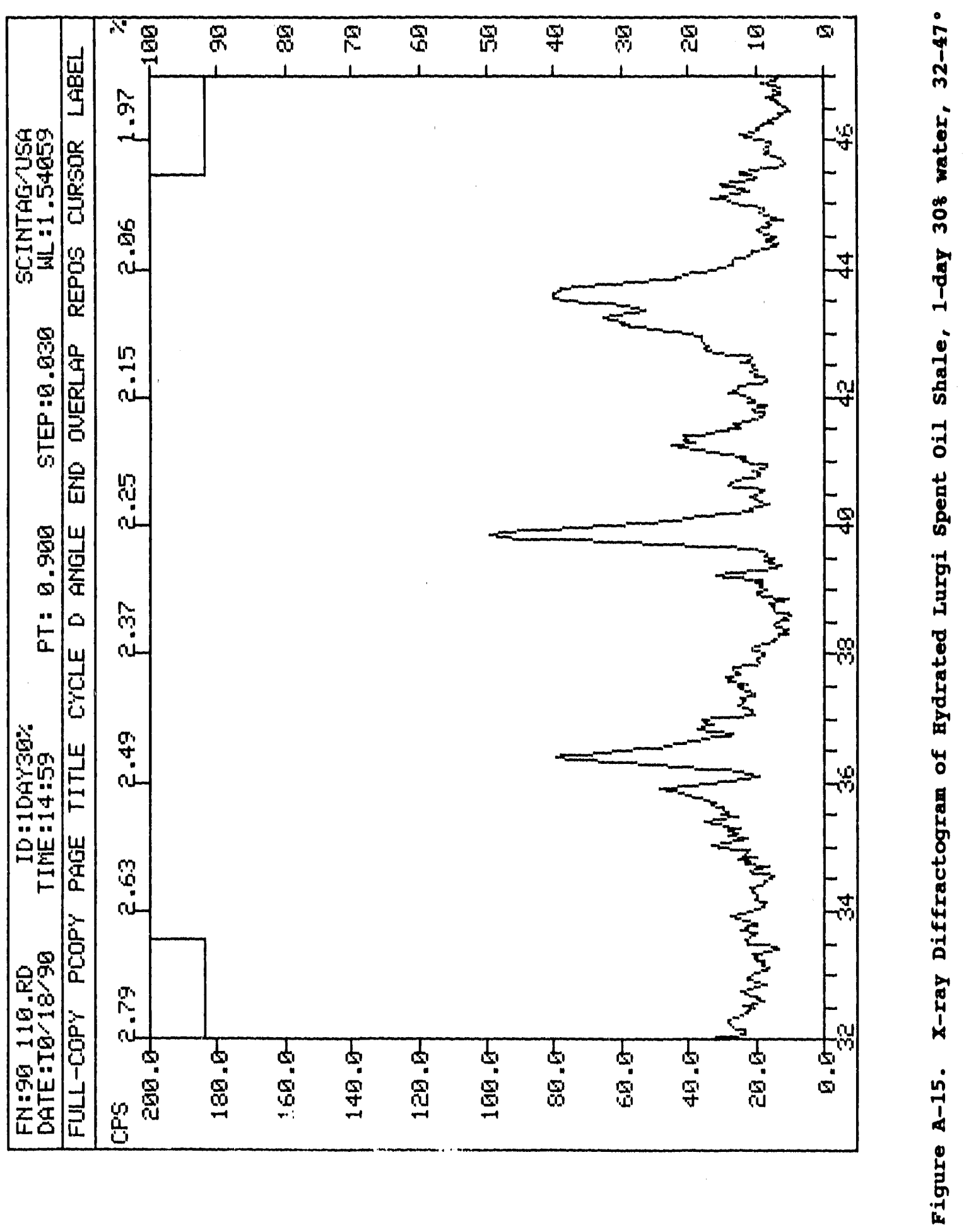




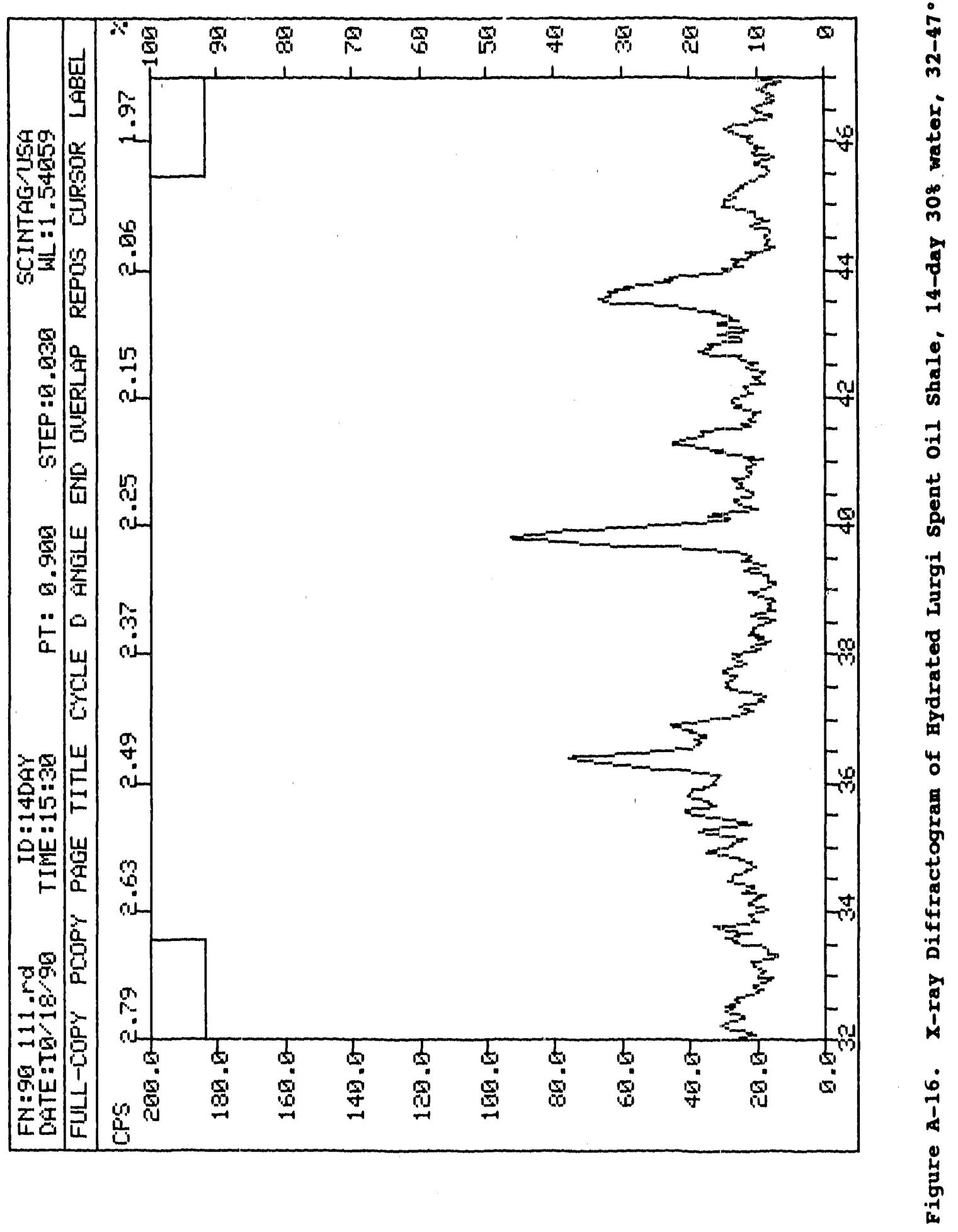




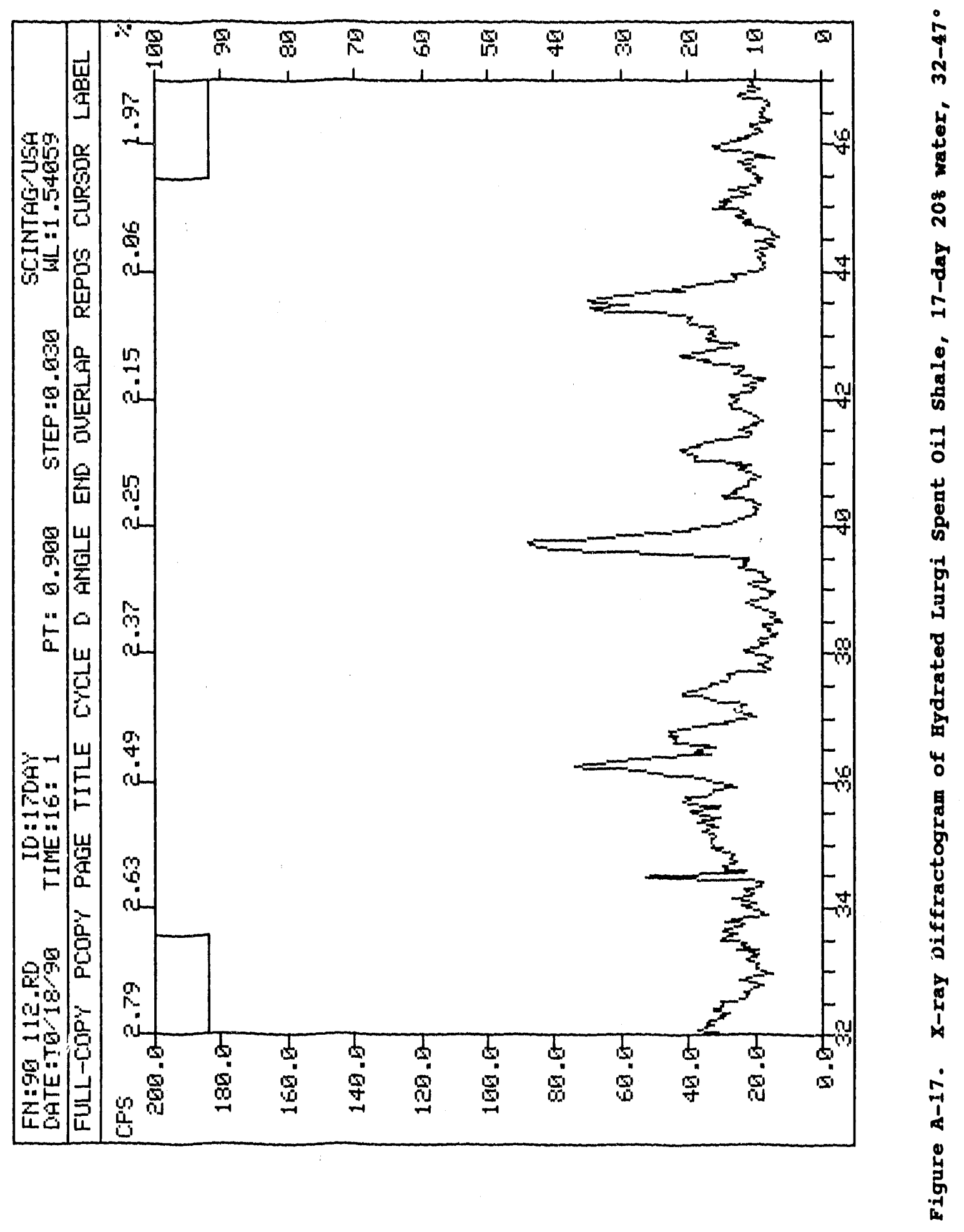




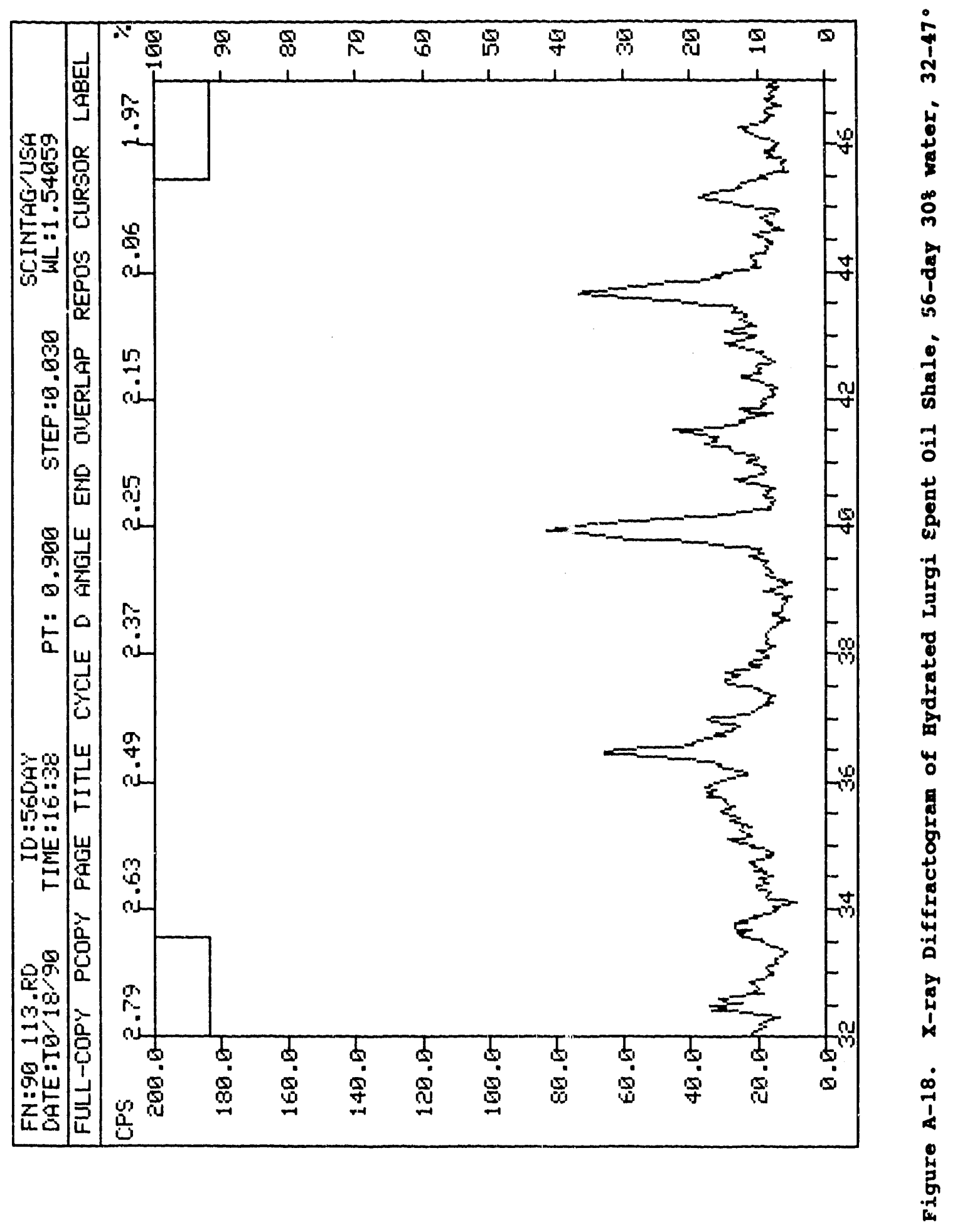




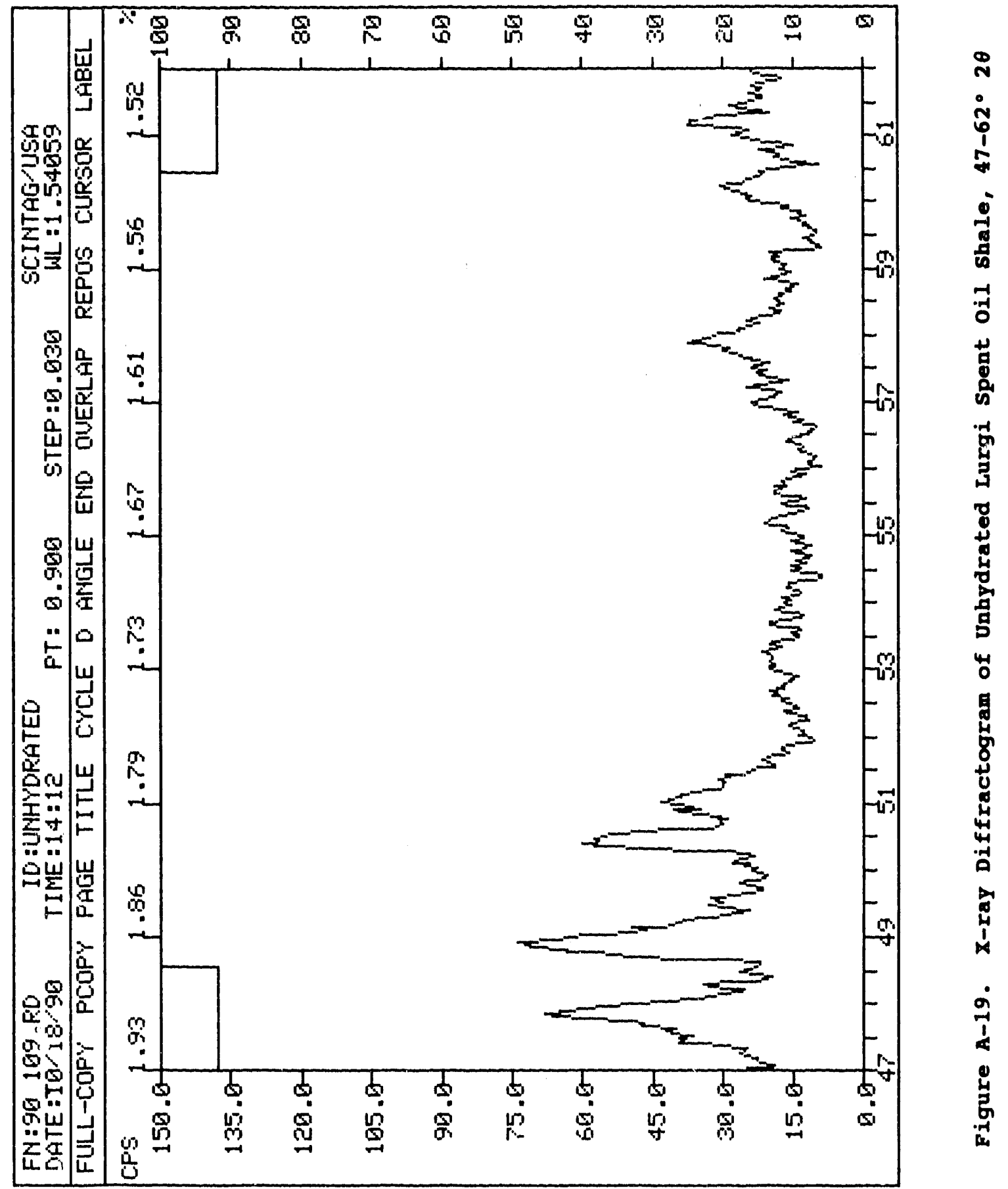




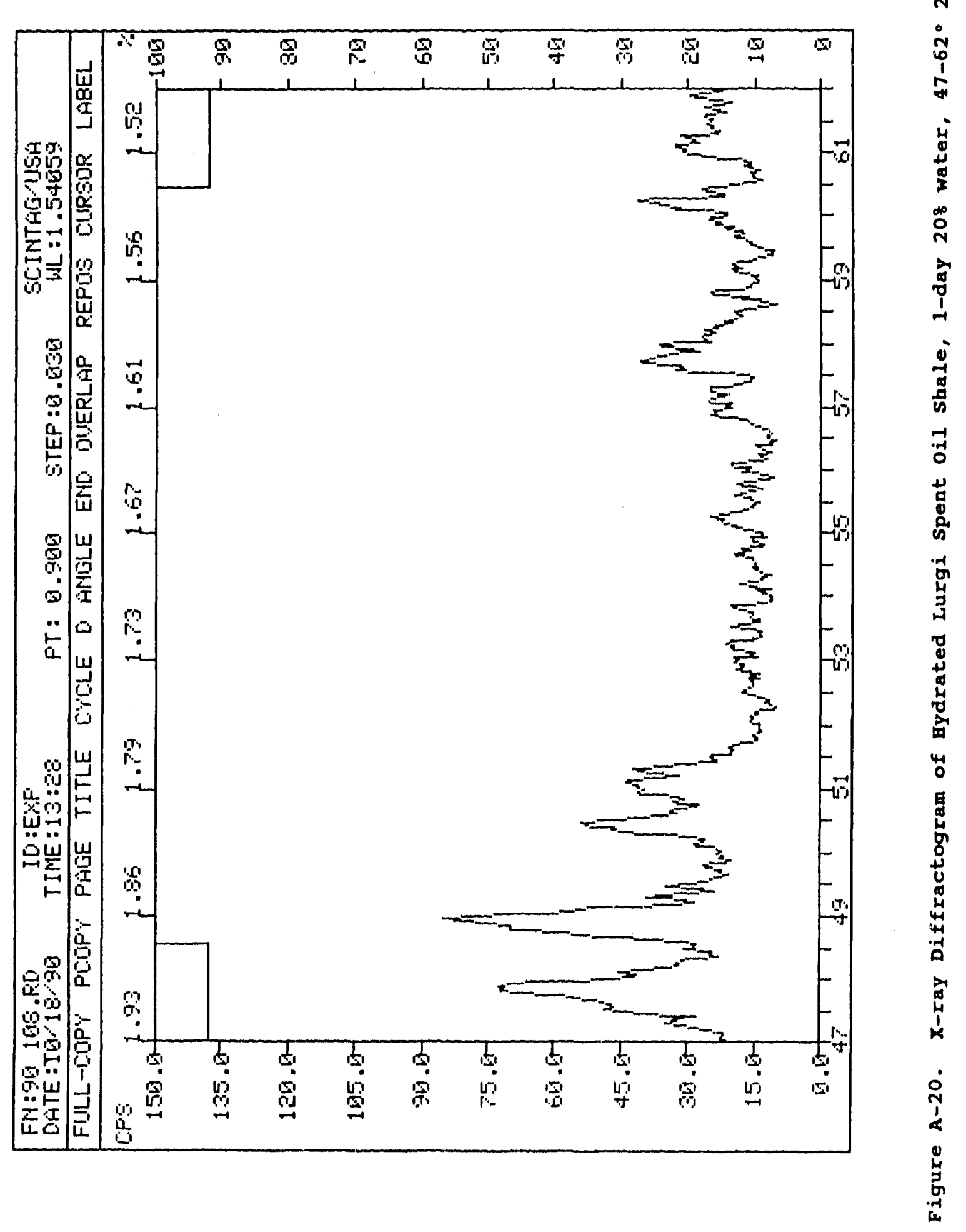




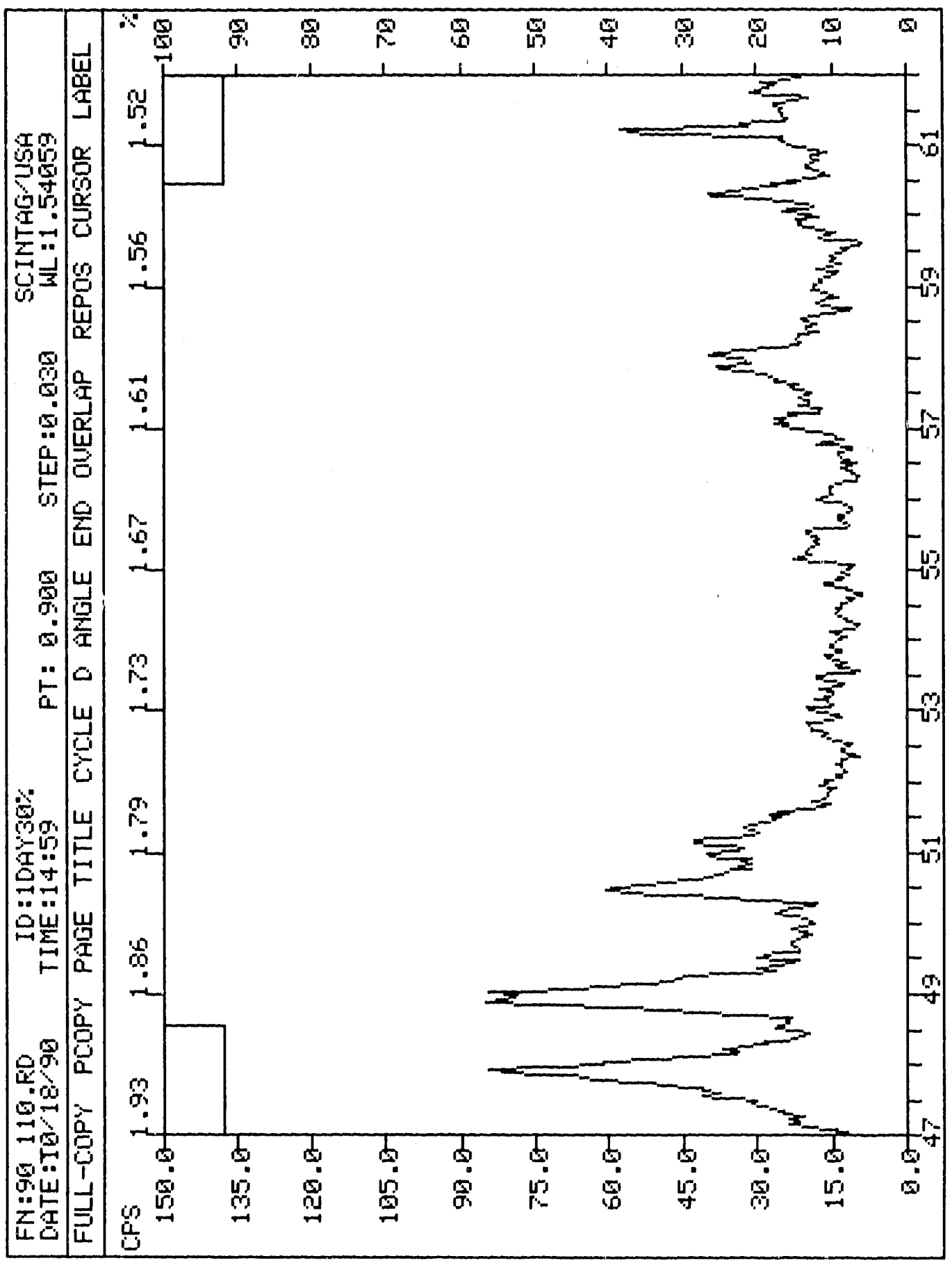

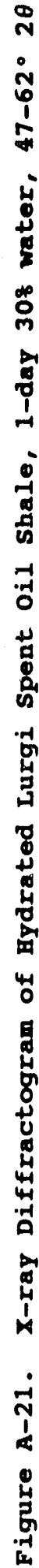




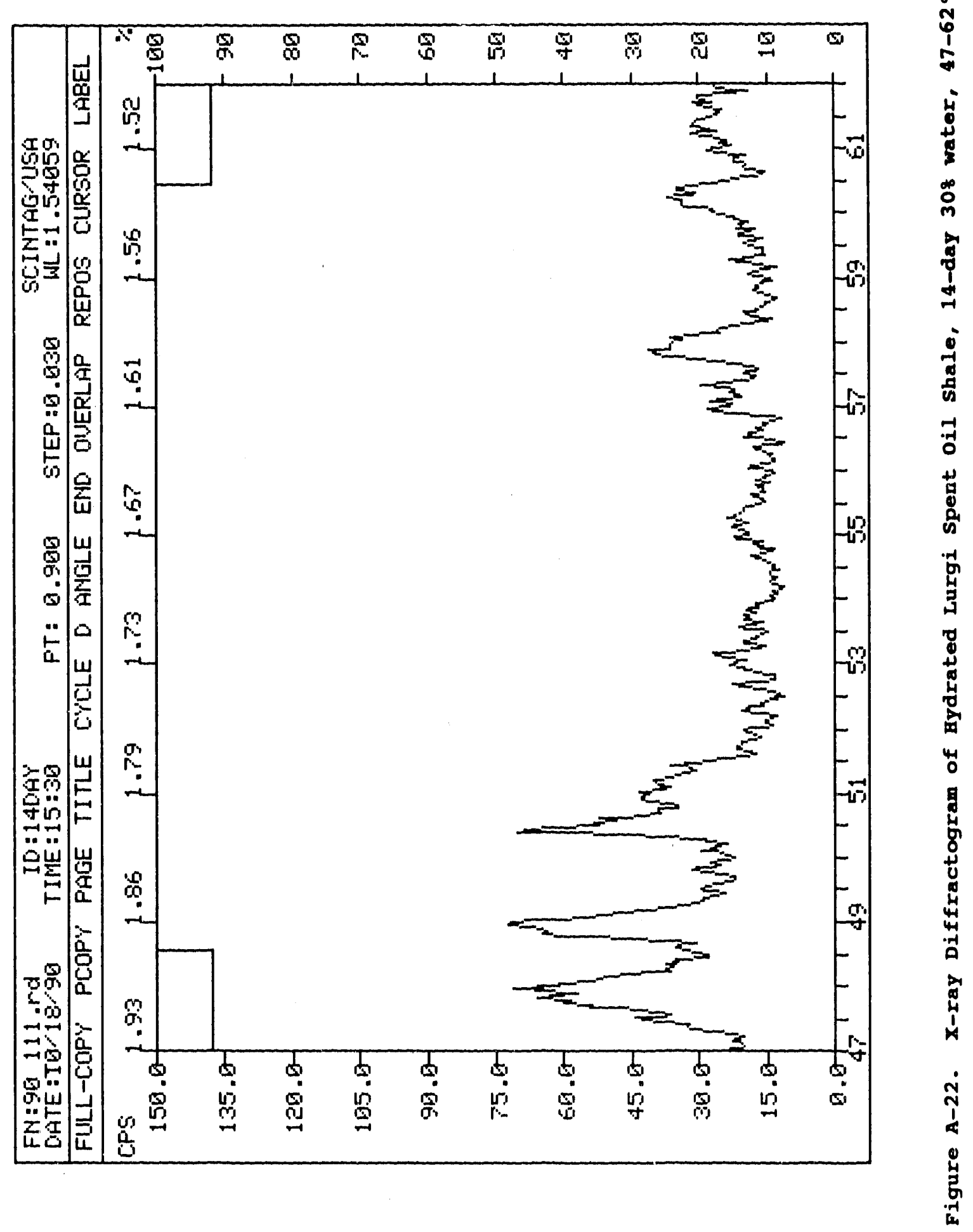




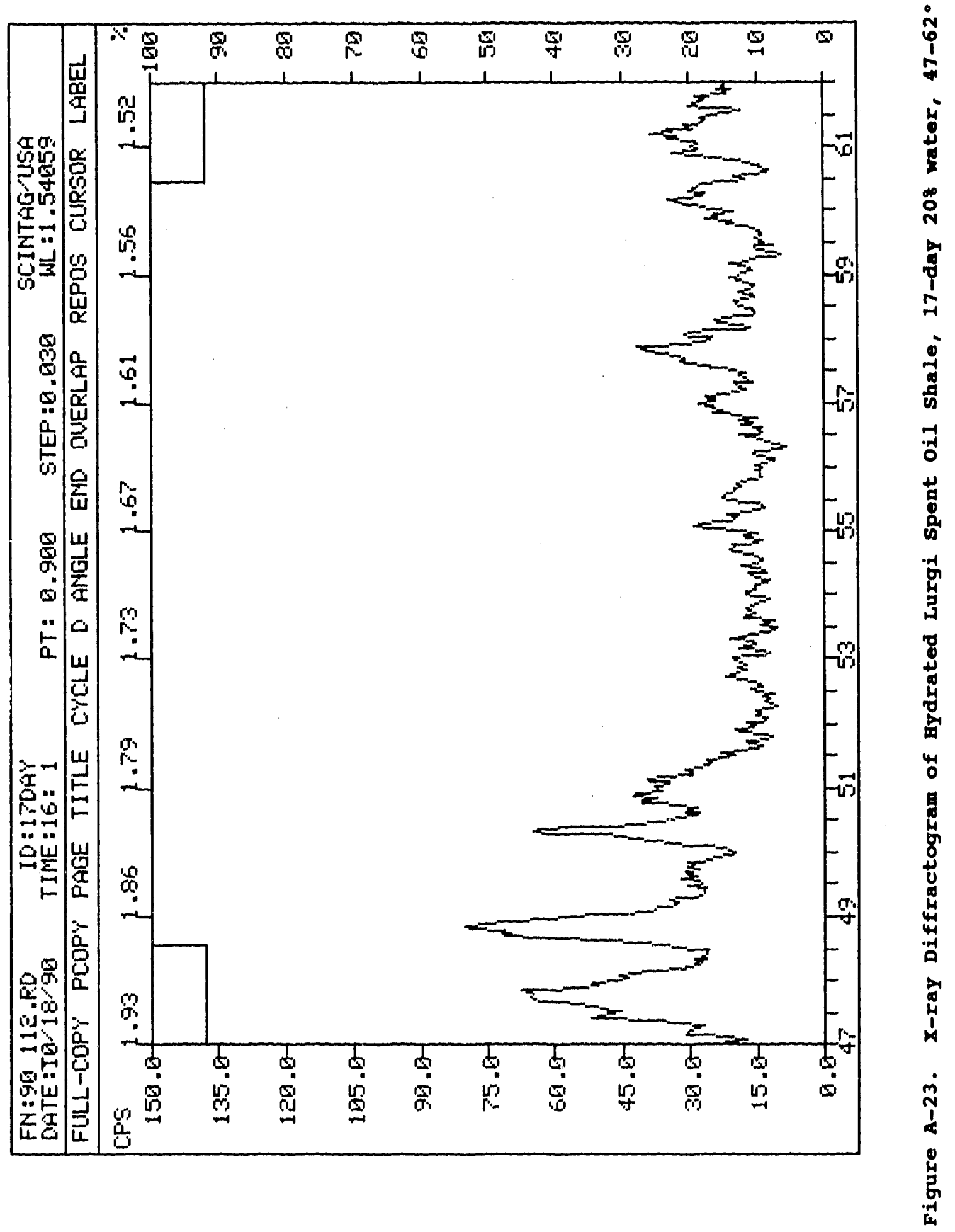




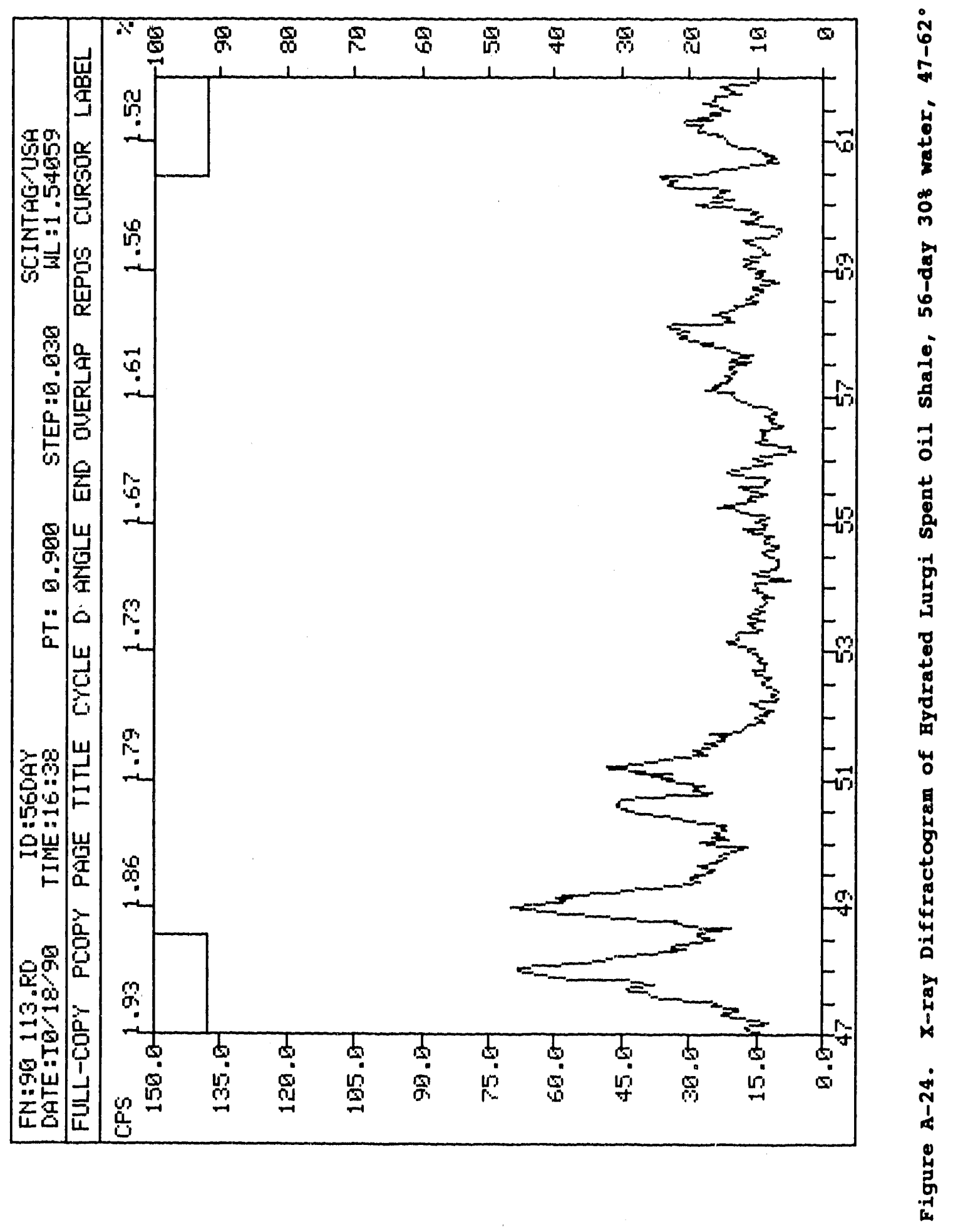


APPENDIX B

Energy Dispersive $X$-ray Analyses 


\section{CONTENTS OF APPENDIX B}

\section{Page}

EDXA of the Rod-Like Crystals in the 17-day 208 Hydrated

Lurgi oil shale................................

EDXA of the Rod-Like Crystals in the 56-day 308 Hydrated

Lurgi oil shale................................. 58

EDXA of the 56-day 308 Hydrated Lurgi oil shale............... 59 

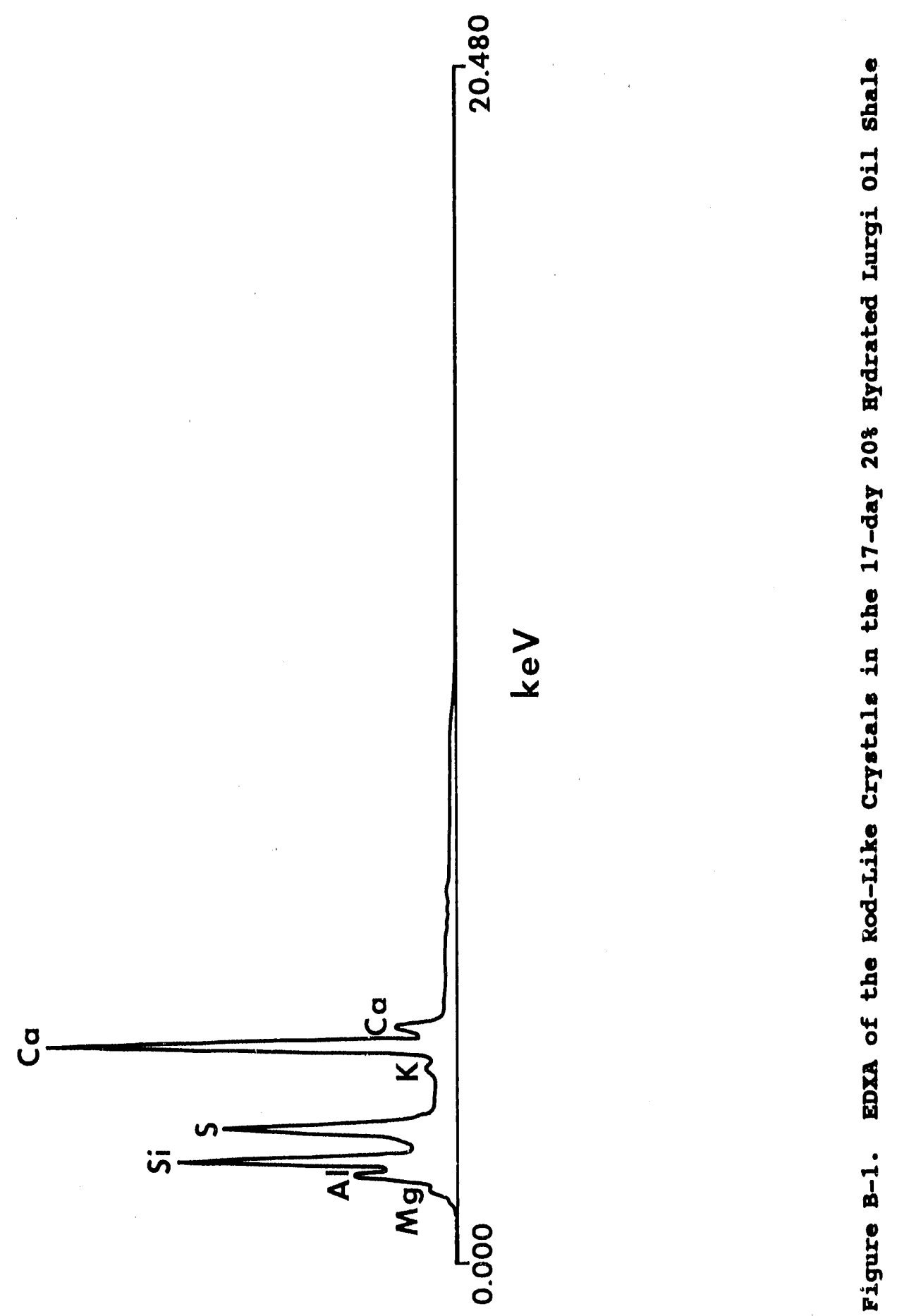

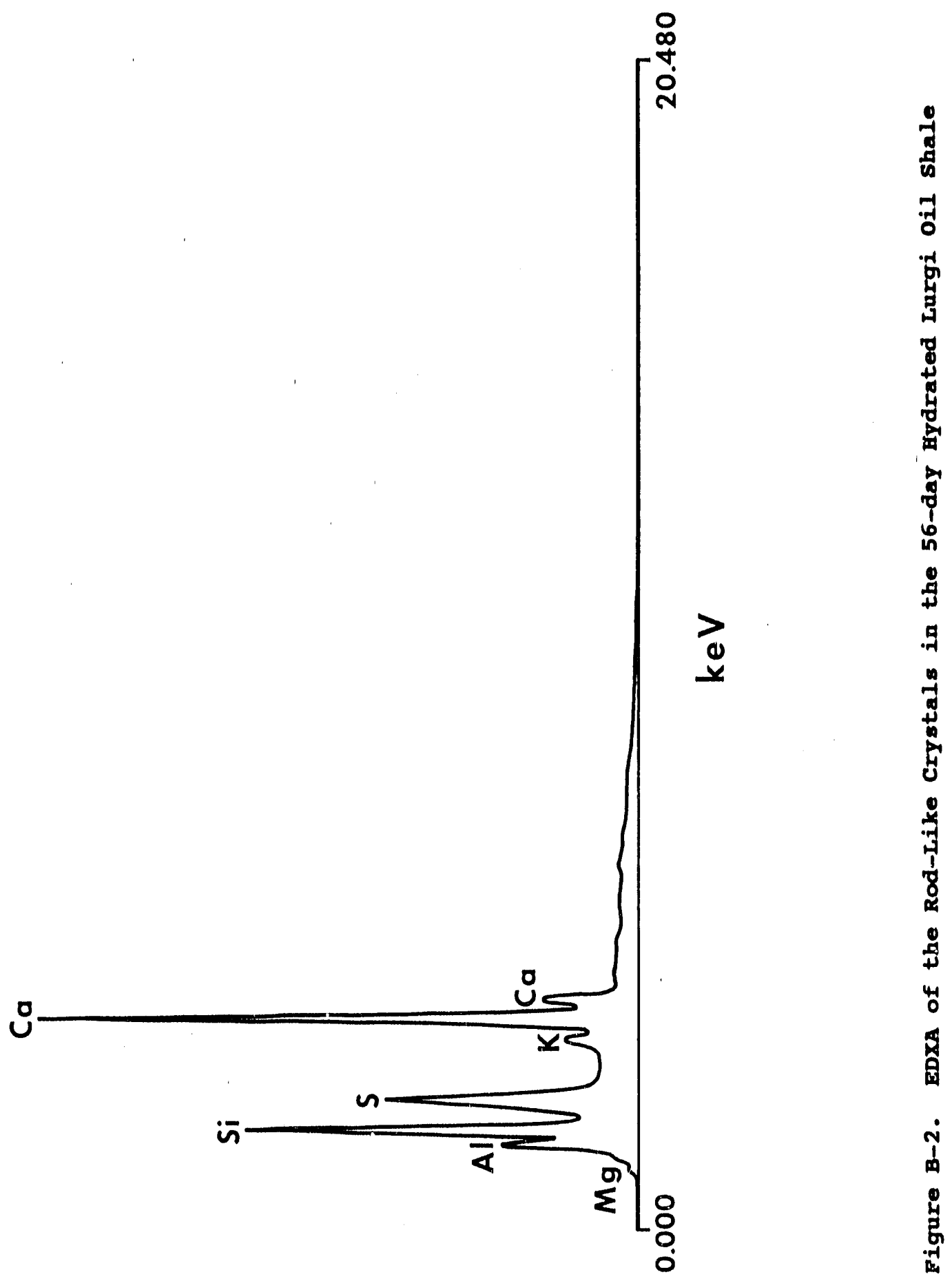


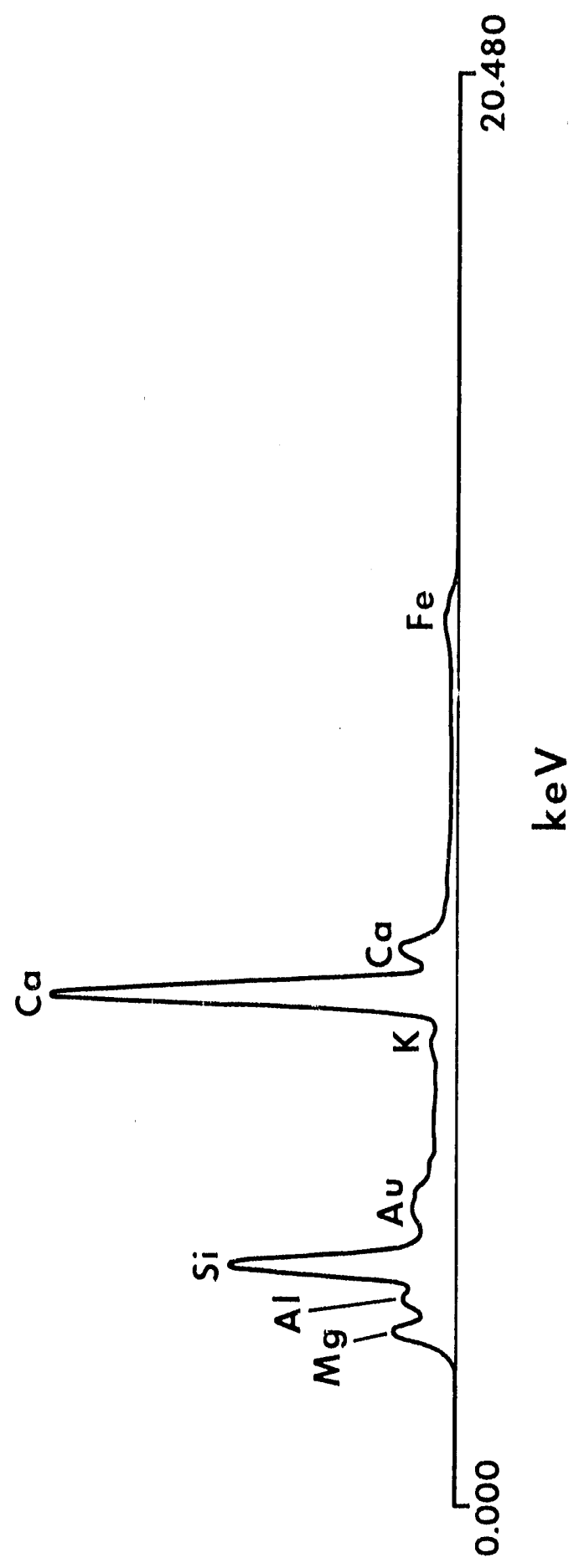

量

今-



8

总

dp

욨

मे

in

通

出

串

m 
圆

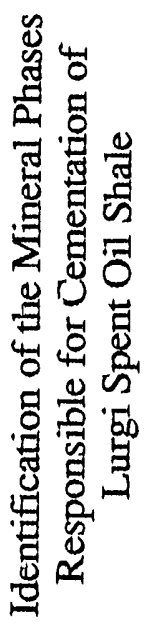

苍 

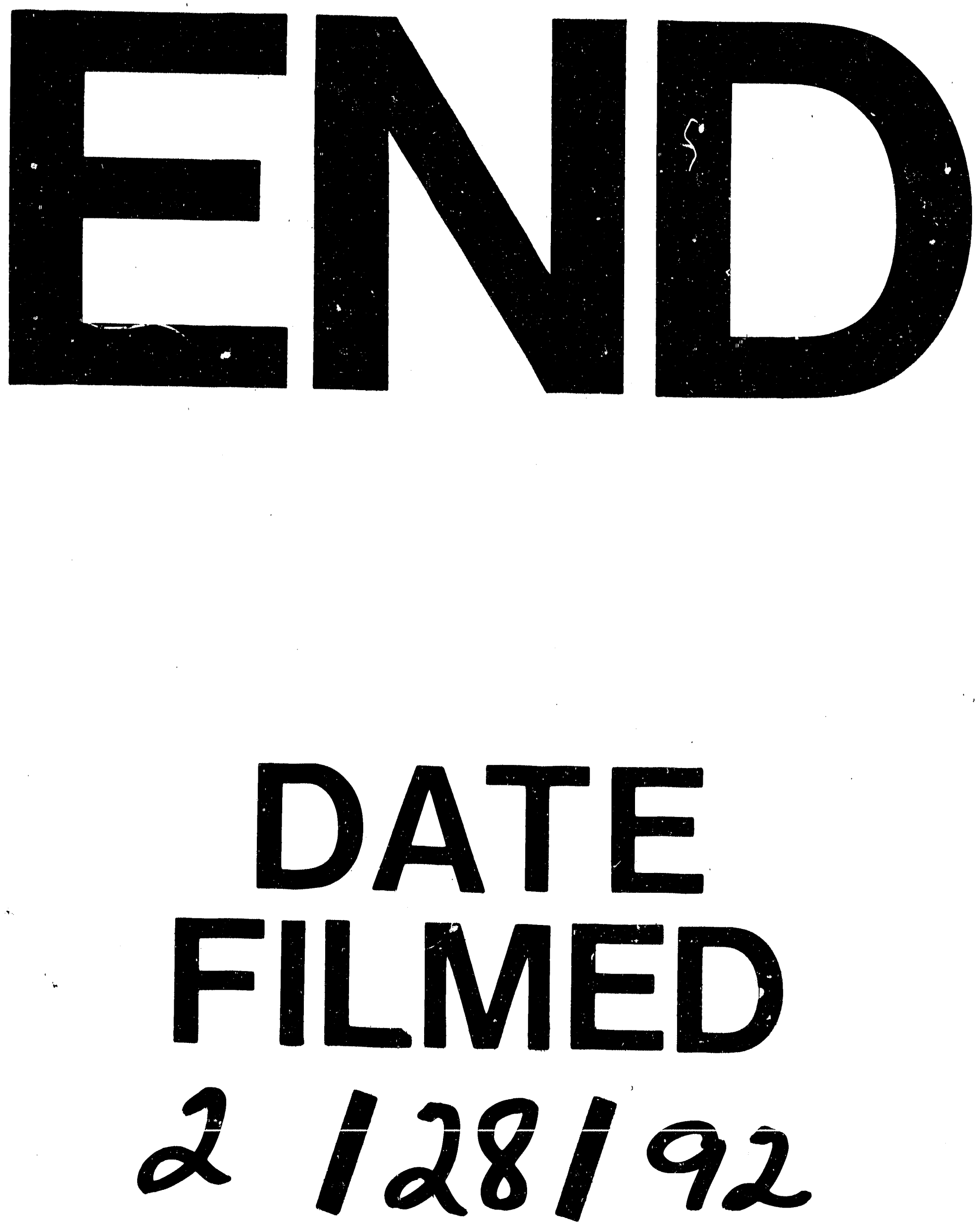